\title{
Store-0perated CRAC Channels Regulate Gene Expression and Proliferation in Neural Progenitor Cells
}

\author{
Agila Somasundaram, ${ }^{1}$ Andrew K. Shum, ${ }^{1}$ Helen J. McBride, ${ }^{4}$ John A. Kessler, ${ }^{3}$ Stefan Feske, ${ }^{2}$ Richard J. Miller, ${ }^{1}$ \\ and Murali Prakriya ${ }^{1}$ \\ ${ }^{1}$ Department of Molecular Pharmacology and Biological Chemistry, Feinberg School of Medicine, Northwestern University, Chicago, Illinois 60611, \\ ${ }^{2}$ Department of Pathology, New York University Langone Medical Center, New York, New York 10016, ${ }^{3}$ Department of Neurology, Northwestern University \\ Feinberg School of Medicine, Northwestern University, Chicago, Illinois 60611, and ${ }^{4}$ Department of Discovery Toxicology, Amgen, Inc., Thousand Oaks, \\ California 91320
}

Calcium signals regulate many critical processes during vertebrate brain development including neurogenesis, neurotransmitter specification, and axonal outgrowth. However, the identity of the ion channels mediating $\mathrm{Ca}^{2+}$ signaling in the developing nervous system is not well defined. Here, we report that embryonic and adult mouse neural stem/progenitor cells (NSCs/NPCs) exhibit store-operated Ca ${ }^{2+}$ entry (SOCE) mediated by $\mathrm{Ca}^{2+}$ release-activated $\mathrm{Ca}^{2+}$ (CRAC) channels. SOCE in NPCs was blocked by the CRAC channel inhibitors $\mathrm{La}^{3+}, \mathrm{BTP} 2$, and 2-APB and Western blots revealed the presence of the canonical CRAC channel proteins STIM1 and Orail. Knock down of STIM1 or Orail significantly diminished SOCE in NPCs, and SOCE was lost in NPCs from transgenic mice lacking Orail or STIM1 and in knock-in mice expressing the loss-of-function Orail mutant, R93W. Therefore, STIM1 and Orail make essential contributions to S0CE in NPCs. SOCE in NPCs was activated by epidermal growth factor and acetylcholine, the latter occurring through muscarinic receptors. Activation of SOCE stimulated gene transcription through calcineurin/NFAT (nuclear factor of activated T cells) signaling through a mechanism consistent with local $\mathrm{Ca}^{2+}$ signaling by $\mathrm{Ca}^{2+}$ microdomains near CRAC channels. Importantly, suppression or deletion of STIM1 and Orail expression significantly attenuated proliferation of embryonic and adult NPCs cultured as neurospheres and, in vivo, in

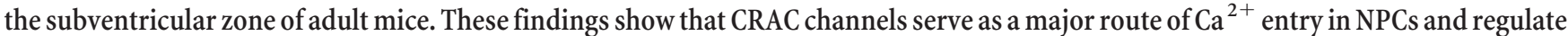
key effector functions including gene expression and proliferation, indicating that CRAC channels are important regulators of mammalian neurogenesis.

Key words: calcium; CRAC channels; Orail; progenitor cell; proliferation; STIM1

\section{Introduction}

Calcium is a ubiquitous second messenger that regulates numerous developmental events in the brain, including neural induction (Leclerc et al., 2000), neurotransmitter specification (Spitzer et al., 2004), growth cone motility (Zheng and Poo, 2007), and neuronal maturation (Nakanishi and Okazawa, 2006). Both spontaneous and agonist-induced $\mathrm{Ca}^{2+}$ signals occur in neural stem/progenitor cells (NSCs/NPCs) and the temporal and spatial

Received Jan. 21, 2014; revised May 1, 2014; accepted May 29, 2014.

Author contributions: A.S., A.K.S., J.A.K., R.J.M., and M.P. designed research; A.S. and A.K.S. performed research; H.J.M. and S.F. contributed unpublished reagents/analytic tools; A.S., A.K.S., and M.P. analyzed data; A.S., A.K.S., and M.P. wrote the paper.

This work was supported by the National Institutes of Health (NIH Grants NS057499 and A1097302) and the Brain Research Foundation. A.S. was supported by an American Heart Association predoctoral fellowship and A.K.S. by an $\mathrm{NIH}$ predoctoral training grant. We thank Lauren T. Sybert, Tammy McGuire, and Paul Mireles for technical help; members of the Prakriya, Kessler, and Miller laboratories for helpful discussions; and Anna Toth and Amit Jairaman for comments on the manuscript.

H.J.M. was an employee of Amgen, Inc. during the design and execution of this work. The remaining authors declare no competing financial interests.

Correspondence should be addressed to Dr. Murali Prakriya, Department of Molecular Pharmacology and Biological Chemistry, Feinberg School of Medicine, Northwestern University, 303 E Chicago Ave., Ward 8-296, Chicago, IL 60605. E-mail: m-prakriya@northwestern.edu.

DOI:10.1523/JNEUROSCI.0263-14.2014

Copyright $\odot 2014$ the authors $\quad 0270-6474 / 14 / 349107-17 \$ 15.00 / 0$ patterns of these $\mathrm{Ca}^{2+}$ signals are widely presumed to control the types of downstream genetic programs that are activated ( $\mathrm{Gu}$ and Spitzer, 1995; Owens and Kriegstein, 1998; Maric et al., 2003; Weissman et al., 2004; Belmadani et al., 2005; Fiorio Pla et al., 2005; Mishra et al., 2006; Lin et al., 2007; Platel et al., 2008). However, the functional architecture of the NSC/NPC Ca ${ }^{2+}$ signaling network and, in particular, the identity and organization of ion channels mediating the $\mathrm{Ca}^{2+}$ signals is not well understood. Some studies have implicated voltage-gated $\mathrm{Ca}^{2+}$ channels as an important route of $\mathrm{Ca}^{2+}$ entry in late stage neural precursors (Maric et al., 2000; D’Ascenzo et al., 2006). However, because NPCs are of neuroectodermal lineage and are largely nonexcitable, it is likely that these cells also use alternate $\mathrm{Ca}^{2+}$ influx pathways of unknown identity.

In many nonexcitable and some excitable cells, store-operated $\mathrm{Ca}^{2+}$ entry (SOCE) is a major mechanism for $\mathrm{Ca}^{2+}$ mobilization (Hogan et al., 2010). Store-operated channels (SOCs) open in response to depletion of $\mathrm{Ca}^{2+}$ in the endoplasmic reticulum (ER) after stimulation of cell surface receptors coupled to G-proteins and tyrosine kinases (Lewis, 2011). The best-described SOCs are the $\mathrm{Ca}^{2+}$ release-activated $\mathrm{Ca}^{2+}$ (CRAC) channels, consisting of the pore-forming Orai proteins that are activated by the $\mathrm{ER} \mathrm{Ca}^{2+}$ sensors STIM1 and STIM2 (Prakriya, 2009). CRAC channel ac- 
tivation occurs through a mechanism by which STIM1 translocates from the bulk ER to junctional ER sites and binds directly to Orail, resulting in accumulation of these two proteins in opposite membranes (Lewis, 2011).

Historically, physiological studies of CRAC channels focused on hematopoetic cells such as $\mathrm{T}$ cells and mast cells, a consequence of the discovery of CRAC currents in these cells (Lewis, 2011). However, recent studies also implicate SOCE in modulating several neuronal functions, including neurotransmitter release (Emptage et al., 2001), synaptic plasticity (Baba et al., 2003), $\mathrm{Ca}^{2+}$ oscillations (Singaravelu et al., 2008), and firing of flight motorneurons in Drosophila (Venkiteswaran and Hasan, 2009). Moreover, aberrant SOCE has been implicated in hypoxiamediated neuronal death (Berna-Erro et al., 2009), epilepsy (Steinbeck et al., 2011), and the response to axonal injury (Gemes et al., 2011). Nevertheless, the molecular mechanisms of SOCE during early neural development and its physiological functions remain poorly understood. In this study, we show that storeoperated CRAC channels encoded by Orail and STIM1 are a major mechanism for $\mathrm{Ca}^{2+}$ entry in mouse subventricular zone NPCs. We also found that CRAC channels regulate calcineurin/ nuclear factor of activated T cells (NFAT)-mediated gene expression and regulate the proliferation of NPCs. These findings establish CRAC channels as a novel mechanism for regulation of $\mathrm{Ca}^{2+}$ signaling, gene expression, and proliferation in NPCs.

\section{Materials and Methods}

Cells and transgenic mice. C57BL/6 mice were cared for in accordance with the Guide for the Care and Use of Laboratory Animals. Animals were pair-housed in a sterile ventilated facility. All research protocols were approved by the Northwestern University Institutional Animal Care and Use Committee. Primary NPCs were isolated from mice of various ages, as indicated in the figures. The first day of the presence of a plug was counted as embryonic day 0 (E0) of gestation. Neurospheres were cultured from the ganglionic eminence (embryonic and neonatal mice) or the anterior subventricular zone (adult mice). Individual cells were dissociated from the tissues of interest and grown at 50,000 cells $/ \mathrm{ml}$ in DMEM:F12 (1:1) growth medium supplemented with, B-27, N-2, 2 mM L-glutamine, $2 \mu \mathrm{g} / \mathrm{ml}$ heparin, and either $10 \mathrm{ng} / \mathrm{ml}$ recombinant human bFGF ( $<$ E15 NPCs), $20 \mathrm{ng} / \mathrm{ml}$ recombinant human EGF ( $>$ E15 NPCs), or $10 \mathrm{ng} / \mathrm{ml}$ each of bFGF and EGF (E15 and adult NPCs). After $4-5 \mathrm{~d}$ in culture, primary neurospheres were dissociated with $0.05 \%$ trypsin for $2 \mathrm{~min}$ at $37^{\circ} \mathrm{C}$, followed by trypsin inhibitor (Sigma-Aldrich) and seeded again. Secondary neurospheres generated from these cells were used for our studies. Orail $1^{\mathrm{R} 93 \mathrm{~W} /+}$ and STIM1 ${ }^{\mathrm{fl} /+ \text { :CMV-Cre }}$ mice have been described previously (Oh-Hora et al., 2008; Bergmeier et al., 2009). STIM1 $11^{\mathrm{fl} /+: \mathrm{CMV}-\text { Cre }}$ mice were bred with $\mathrm{STIM} 1^{\mathrm{fl} /+}$ mice to obtain STIM1 ${ }^{\mathrm{fl} /}-$ mice. CMV-Cre was bred out.

Tissue-specific deletion of Orail in the brain was achieved by crossing Orail ${ }^{\mathrm{fl} / \mathrm{fl}}$ mice (Amgen) with nestin-Cre mice (The Jackson Laboratory). To generate the Orai $\mathrm{f}^{\mathrm{fl} / \mathrm{fl}}$ mice, genomic DNA containing Orail was retrieved from a BAC clone. The overall scheme is detailed in Figure 3. The first loxP site was inserted into intron 1 at $\sim 1 \mathrm{~kb}$ upstream of exon 2 and the second loxP site, along with the Frt-PGKneo-Frt cassette, was inserted $\sim 0.3 \mathrm{~kb} \mathrm{3}$ ' of exon 3 downstream of the polyA signal sequence and 3' UTR. The targeting vector was linearized by NotI digestion, purified, and electroporated into C57BL/6N ES cells. Cells that integrated the targeting vector were selected with $200 \mathrm{mg} / \mathrm{ml} \mathrm{G} 418$ and selected clones were screened by PCR. Four potential clones were expanded and screened by Southern blot for the $5^{\prime}-, 3^{\prime}-$, and Neocontaining portions of the vector. Two of the four clones were confirmed by Southern blot to contain the targeted vector. Flp electroporation was performed for both clones to delete the Neo cassette. Six Neodeleted clones were identified after selection and confirmed upon expansion by PCR analysis using the following primers: Neo DelF $5^{\prime}-$ CAGCGTGCATAATATACCTAACTCTACCCG-3' Neo DelR 5'-GTA
TTGATGAgGAGAGCAAGCGTGAATC- $3^{\prime}$ ). The presence of the $3^{\prime}$ Lox site in these clones was also confirmed by PCR (LoxPF 5' -GAAATGGCTCGGGGACAAAACACTA-3' LoxPR 5'-GCCATTTCTGGTCTTCTGGAGACTCTG-3'). Blastocyst injection was performed with two of the Neo-deleted clones to generate male chimeras that were subsequently bred to wild-type (WT) C57BL/6N females to produce heterozygous animals suitable for expansion of the line and breeding to homozygosity. Genotyping was performed by PCR using the NeoDel primers. WT animals generate a single band of $\sim 0.22 \mathrm{~kb}$ and loxP animals produce a band of $\sim 0.36 \mathrm{~kb}$ using these primers.

Interestingly, in addition to conditional deletion of Orail in the brain, the Orai1 ${ }^{\mathrm{f} / / \mathrm{fl}} \times$ nestin-Cre cross also produced germline transmission in a few instances, yielding Orail ${ }^{\mathrm{fl} /-}$ genotypes. Orail ${ }^{\mathrm{fl} /-}$ mice were then intercrossed to obtain Orail ${ }^{-1-}$ germline-knock-out $(\mathrm{KO})$ embryos. Deletion was verified using the following primers: 5'-GGG ACA AAA CAC TAA CCT GTC AT- ${ }^{\prime}, 5^{\prime}$-GGA GTA GAA TTC AGT GGG AGA GT- ${ }^{\prime}$, and $5^{\prime}$-TAT GGT AAG GCT GGG AGA CAC- ${ }^{\prime}$. The expected size of the PCR products are as follows: WT $\sim 131 \mathrm{bp}$, floxed $\sim 257 \mathrm{bp}$, and $\mathrm{KO} \sim 207 \mathrm{bp}$.

Solutions and chemicals. The standard Ringer's solution used for $\mathrm{Ca}^{2+}$-imaging studies contained the following (in mM): $155 \mathrm{NaCl}, 4.5$ $\mathrm{KCl}, 10$ D-glucose, $5 \mathrm{HEPES}, 1 \mathrm{MgCl}_{2}$ and $2 \mathrm{CaCl}_{2}$. The $\mathrm{Ca}^{2+}$-free Ringer's solution contained $3 \mathrm{~mm} \mathrm{MgCl}, 1$ mm EGTA (Sigma-Aldrich), and no added $\mathrm{CaCl}_{2}$. $\mathrm{pH}$ was adjusted to 7.4 with $1.0 \mathrm{~N} \mathrm{NaOH}$. Stock solutions of thapsigargin, nifedipine, 2-aminoethyldiphenylborate, ionomycin, phorbol 12,13-dibutyrate (PDBu), cyclosporine A, tetrodotoxin (all Sigma-Aldrich) and YM-58483 (BTP-2; Calbiochem) were dissolved in DMSO and used at the indicated concentrations. SKF96365, muscarine chloride, methyllycaconitine citrate, and dihydro- $\beta$-erythroidine (all Sigma-Aldrich) were dissolved in water. EGTA-AM and BAPTA-AM were obtained from Invitrogen.

Plasmids and nucleofection. NPCs were nucleofected using the Amaxa nucleofection kit (Lonza) according to the manufacturer's instructions. Dissociated neurospheres were grown for 12-16 h before nucleofection. The E106A Orail-YFP plasmid has been described previously (NavarroBorelly et al., 2008). GFP-NFAT1 was a kind gift from Anjana Rao (Harvard University). The pGL3-NFAT-Luc and pRL-Tk-Luc vectors were obtained from Richard Lewis (Stanford University). siSTIM1 and siOrail were purchased from Ambion. Experiments were performed 24-48 $\mathrm{h}$ after nucleofection.

Calcium imaging. Dissociated neurospheres were plated onto poly-Dlysine-coated glass coverslips in growth medium containing low bFGF $(0.5 \mathrm{ng} / \mathrm{ml})$ or low EGF $(1.0 \mathrm{ng} / \mathrm{ml})$. Cells were incubated with $2 \mu \mathrm{M}$ fura-2-AM (Invitrogen) in growth medium for $15 \mathrm{~min}$ at $37^{\circ} \mathrm{C}$. Excess fura- 2 was washed off and cells were incubated for an additional $15 \mathrm{~min}$ at $37^{\circ} \mathrm{C}$ before imaging. Single-cell $\mathrm{Ca}^{2+}$ measurements were performed within $4-10 \mathrm{~h}$ of plating to prevent confounding effects due to differentiation of NPCs. $\mathrm{Ca}^{2+}$ imaging was performed as described previously (McNally et al., 2012). All experiments were performed at room temperature. TTX $(0.25 \mu \mathrm{M})$ was added to Ringer's solutions to prevent any depolarization-induced $\mathrm{Ca}^{2+}$ influx. $\left[\mathrm{Ca}^{2+}\right]_{i}$ was estimated using the standard equation (Grynkiewicz et al., 1985) as follows:

$$
\left[C a^{2+}\right]_{i}=Q K_{d}\left(R-R_{\min }\right) /\left(R_{\max }-R\right)
$$

where $R$ is the $F_{340} / F_{380}$ fluorescence ratio and values of $R_{\min }$ and $R_{\max }$ were estimated from an in situ calibration of fura-2. $R_{\min }$ and $R_{\max }$ were determined from the fluorescence ratios with solutions containing $1 \mathrm{~mm}$ EGTA or $20 \mathrm{mM} \mathrm{Ca}^{2+}$ Ringer's solutions together with $2 \mu \mathrm{M}$ ionomycin, respectively. $Q$ was determined from the $F_{\min } / F_{\max }$ ratio at $380 \mathrm{~nm}$ and $K_{d}$ is the apparent dissociation constant of fura-2 binding to $\mathrm{Ca}^{2+}(135$ $\mathrm{nM})$. The values of these parameters were as follows: $R_{\min }=0.32 \pm 0.04$, $R_{\max }=3.09 \pm 0.13$, and $Q=5 \pm 0.32$.

Western blots. Neurospheres were washed with cold PBS and lysed in buffer containing $150 \mathrm{~mm} \mathrm{NaCl}, 50 \mathrm{~mm}$ Tris, $1 \%$ Triton X-100, $0.1 \%$ SDS, and $1 \times$ protease inhibitor mixture (Sigma-Aldrich) by incubating on ice for $15 \mathrm{~min}$. Lysates were centrifuged at $4^{\circ} \mathrm{C}$ for $30 \mathrm{~min}$ and supernatants were stored at $-80^{\circ} \mathrm{C}$. Isolated protein samples were heated to $65^{\circ} \mathrm{C}$ in Laemmli sample buffer (Bio-Rad) containing $5 \%$ 
$\beta$-mercaptoethanol and run on $10 \%$ SDS-polyacrylamide gel. Protein was transferred onto nitrocellulose membrane and Orail and STIM1 were detected using purified polyclonal primary antibodies (Gwack et al., 2008; Oh-Hora et al., 2008) and peroxidase-labeled secondary antibodies. Nestin antibody was purchased from BD PharMingen. Western blot images were analyzed using the image analysis software ImageJ.

NFAT-luciferase assays. NFAT activity in NPCs was assayed using luciferase activity of an NFAT-dependent luciferase construct, pGL3NFAT (Dolmetsch et al., 1998). The NFAT-driven firefly luciferase activity was normalized to the constitutively active renilla luciferase ( $p R L-T k-L u c$ ) activity to correct for variations in cell density. NPCs were nucleofected with the pGL3-NFAT-luc and pRL-Tk-Luc vectors at a ratio of 3:1 24-48 h before experiments. Cells were treated with CRAC channel inhibitors for $\sim 3 \mathrm{~h}$, followed by stimulation with $0.5 \mu \mathrm{M}$ thapsigargin (TG) and $100 \mathrm{~nm}$ PDBu for 6-13 h; $0.5 \mu \mathrm{M}$ TTX and $5 \mu \mathrm{M}$ nifedipine were present throughout to prevent $\mathrm{Ca}^{2+}$ influx through voltage-gated $\mathrm{Ca}^{2+}$ channels. Cells were lysed and luciferase activity was measured using the Dual Luciferase Reporter Assay kit (Promega) and a single tube luminometer (Berthold Instruments).

Immunostaining. Dissociated NPCs were plated on coverslips and fixed $16 \mathrm{~h}$ after plating with $4 \% \mathrm{PFA}$ in PBS for $15 \mathrm{~min}$ at $4^{\circ} \mathrm{C}$. Cells were washed with PBS, permeabilized using $0.1 \%$ Triton X-100 for $30 \mathrm{~min}$, followed by blocking in $1 \%$ bovine serum albumin in PBS for $1 \mathrm{~h}$. Cells were incubated with primary antibodies at 1:500 for nestin (BD PharMingen), 1:500 for Orail (mAb 266.1; Amgen), 1:1000 for GFAP (Sigma-Aldrich), and 1:500 for doublecortin (Abcam) for $1 \mathrm{~h}$, followed by secondary antibody tagged to Alexa Fluor 488 or Alexa Fluor 594 (Invitrogen) at 1:500 or 1:1000 for $1 \mathrm{~h}$. Nuclei were labeled with DAPI.

Proliferation assays. In vitro NPC proliferation was assessed using the Click-iT 5-ethynyl-2'-deoxyuridine (EdU) proliferation kit (Invitrogen). Briefly, secondary neurospheres were treated with EdU for $\sim 3 \mathrm{~h}$, followed by dissociation, fixation, and staining for EdU using an Alexa Fluor 488 conjugate according to manufacturer's instructions (Morte et al., 2013). DNA was labeled using 7-amino-actinomycin D (7-AAD). Flow analysis was performed on an LSR Fortessa Analyzer (BD). Alexa Fluor 488 and 7-AAD were excited at 488 and $552 \mathrm{~nm}$, respectively, and emission signals were collected using 530 and $670 \mathrm{~nm}$ band-pass filters, respectively. At least 20,000 cells were collected for each sample. Analysis was restricted to single cells; doublet discrimination was achieved using area and width signals in the 7-AAD channels or using area and height signals in the forward scatter. MTT proliferation assays were performed using the MTT assay kit (Promega). Cells were plated at a density of 5000 cells per well of a 96-well plate; $15 \mu \mathrm{l}$ of MTT reagent was added to each well at various time points after plating. The solubilization buffer was added $3 \mathrm{~h}$ later and absorbance was measured at $595 \mathrm{~nm}$.

In vivo bromodeoxyuridine (BrdU) incorporation assays in tissue slices were performed on 4- to 6-week-old mice. Mice were injected intraperitoneally with a single dose of $50 \mathrm{mg} / \mathrm{kg}$ BrdU dissolved in saline and killed $24 \mathrm{~h}$ later after anesthetization with isofluorane. Anesthetized mice were perfused intracardially with saline and then 4\% PFA in PBS and decapitated. Brains were postfixed for $24 \mathrm{~h}$ in $4 \%$ PFA, cryoprotected for $24 \mathrm{~h}$ in $30 \%$ sucrose at $4^{\circ} \mathrm{C}$, embedded in optimal cutting temperature medium, and cryosectioned at $20 \mu \mathrm{m}$ thickness. Immunolabeling for BrdU was performed on every third section containing the anterior SVZ. Sections were incubated in sheep anti-BrdU (Fitzgerald Laboratories) at a 1:500 dilution overnight at $4^{\circ} \mathrm{C}$, followed by biotinylated donkey antisheep (Jackson Laboratories) at 1:250 for $2 \mathrm{~h}$ at room temperature (RT) and Alexa Fluor 546-conjugated streptavidin (Invitrogen) at 1:100 for 45 min at RT. Nuclei were stained using DAPI. Immunolabeled sections were imaged using an Olympus FV10i confocal microscope at a magnification of $60 \times$ and image thickness of $1 \mu \mathrm{m}$. BrdU ${ }^{+}$cells were counted in each section and averaged per section.

Apoptosis assays. The fraction of apoptotic cells in cultured NPCs was estimated using a kit (Invitrogen) that measures the differential permeability of the DNA dyes 7-AAD and PO-PRO-1 (Benzoxazolium, 3-methyl-2-[[1[3-(trimethylammonio)propyl]-4(1H)-pyridinylidene]methyl]-, diiodide) to live, dead, and apoptotic cells. Dissociated neurospheres were washed with $1 \times$ cold PBS, incubated with $2.5 \mu \mathrm{M}$ PO-PRO- 1 and $1 \mu \mathrm{g} / \mathrm{ml}$ 7-AAD for 30 min on ice, and analyzed by flow cytometry. The detection of apoptotic cells in brain sections was estimated by terminal deoxynucleotidyl transferase (TUNEL) staining, which fluorescently labels DNA fragmentation. Briefly, sections were permeabilized using $0.1 \%$ sodium citrate/ $0.1 \%$ Triton for 2 min at $4^{\circ} \mathrm{C}$, and then washed with $1 \times$ PBS. Positive control sections were treated with DNaseI (at $500 \mathrm{U} / \mathrm{ml}$ ) for $10 \mathrm{~min}$ at room temperature. All sections were treated with a mixture of TUNEL enzyme and fluoresceinlabeled nucleotides except for the negative control, which was treated with a mixture lacking enzyme. The reaction was performed at $1 \mathrm{~h}$ at $37^{\circ} \mathrm{C}$. Sections were washed in $1 \times$ PBS and mounted with Vectashield mounting medium containing DAPI. Images were taken on the FV10i Olympus confocal microscope.

Data analysis. All data are expressed as mean \pm SEM. Statistical analysis was performed using either a two-tailed $t$ test (paired or unpaired as indicated) for comparison between the control and test groups or ANOVA (one- or two-factor as indicated in the figure legends) at 5\% confidence interval, followed by post hoc two-tailed paired $t$ tests to compare between conditions. The data were assumed to be parametric. Results with $p \leq 0.05$ were considered significant.

\section{Results}

Many types of $\mathrm{Ca}^{2+}$ signals have been described in the immature nervous system (Gu and Spitzer, 1995; Owens and Kriegstein, 1998; Weissman et al., 2004); however, the identity of the $\mathrm{Ca}^{2+}$ channels that generate these signals is not well understood. Here, we investigated the role of store-operated CRAC channels for $\mathrm{Ca}^{2+}$ signaling and effector function in NPCs. For these studies, we cultured NPCs and analyzed brain slices from C57BL/6 mice from various developmental ages. The contribution of CRAC channels for SOCE and effector function was examined through pharmacological and genetic approaches using transgenic mice lacking CRAC channel proteins or expressing a nonfunctional CRAC channel, R93W Orail (Bergmeier et al., 2009).

\section{Mouse NPCs exhibit SOCE}

SOCs are activated by reduction in the $\mathrm{ER} \mathrm{Ca}^{2+}$ concentration (Lewis, 2011). To determine whether NPCs exhibit SOCE, we depleted ER stores using $1 \mu \mathrm{M}$ TG in a $\mathrm{Ca}^{2+}$-free Ringer's solution and studied $\mathrm{Ca}^{2+}$ influx after re-addition of extracellular $\mathrm{Ca}^{2+}$ (Fig. 1). This experiment revealed prominent SOCE in NPCs after re-addition of external $\mathrm{Ca}^{2+}$ (Fig. 1B). We found that SOCE was present in NPCs derived from embryonic (E13-E18), neonatal (P0-P2, P5), and adult mice (Figs. 1, 2, 3 and data not shown). Moreover, the amplitude of SOCE was not different between embryonic and adult NPCs (cf. Figs. $2 H, I, 3 D, E$ ), indicating that this $\mathrm{Ca}^{2+}$ entry mechanism is conserved throughout development and is not unique to NPCs from mice of a particular age.

The best-described SOCs are CRAC channels, which are distinguished by high $\mathrm{Ca}^{2+}$ selectivity and a unique pharmacological profile (Lewis, 2011; McNally and Prakriya, 2012; Jairaman and Prakriya, 2013). We found that SOCEs in NPCs shared many pharmacological hallmarks of CRAC channels, including blockade by a low concentration $(2 \mu \mathrm{M})$ of $\mathrm{La}^{3+}$ (Fig. $\left.1 A\right)$ and modulation by the compound 2-aminoethyldiphenylborate (2-APB). In the latter case, a low dose of 2 -APB $(5 \mu \mathrm{M})$ potentiated influx (data not shown), whereas higher doses of $10 \mu \mathrm{M}$ or above caused transient potentiation followed by inhibition (Fig. 1B), as described previously for CRAC channels (Prakriya and Lewis, 2001). Furthermore, the potent CRAC channel inhibitor BTP-2 (Zitt et al., 2004) strongly inhibited SOCE in NPCs (Fig. 1C). Therefore, the pharmacological profile of SOCE in mouse NPCs is consistent with those of CRAC channels (Jairaman and Prakriya, 2013). 
A

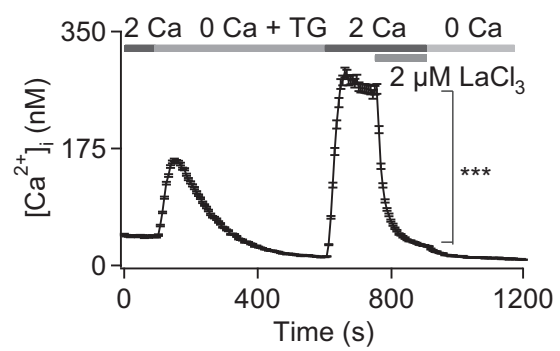

B

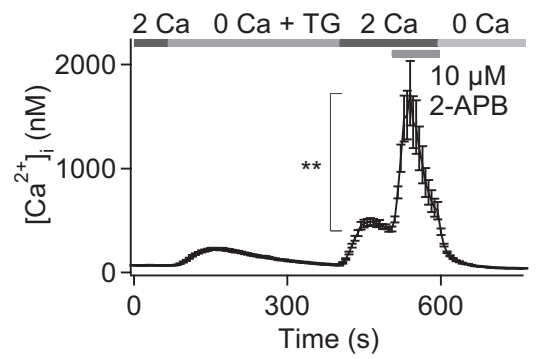

C

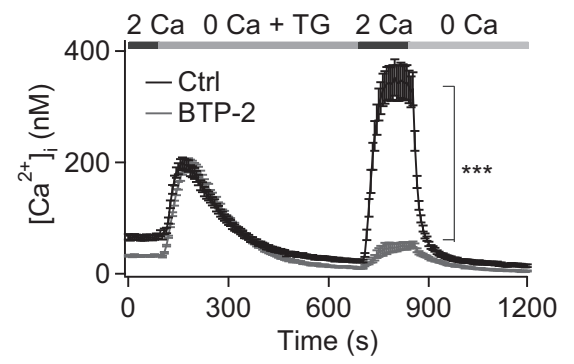

Figure 1. Mouse NPCs exhibit SOCE with pharmacological properties consistent with CRAC channels. A, Depletion of ER $\mathrm{Ca}^{2+}$ stores evokes $\mathrm{La}^{3+}{ }^{3+}$-sensitive SOCE. ER Ca ${ }^{2+}$ stores were depleted with $1 \mu \mathrm{M}$ TG in a $\mathrm{Ca}^{2+}$-free Ringer's solution and extracellular $\mathrm{Ca}^{2+}$ was re-added to evoke SOCE. SOCE is blocked by $2 \mu \mathrm{M} \mathrm{LaCl}\left(\mathrm{E}_{18}\right.$; ${ }^{* * *} p<0.001$ by 2-tailed unpaired $t$ test; $n=80$ cells; representative of experiments from 4 cultures of NPCs cultured from E18 embryos). B. The CRAC channel modulator 2-APB (10 $\mu \mathrm{M})$ produces dual effects on SOCE in NPCs. Administration of 2-APB caused transient potentiation, followed by inhibition, as described previously for CRAC channels (Prakriya and Lewis, 2001; E13, ${ }^{* *} p<0.01,2$-tailed unpaired $t$ test; $n=14$ cells, representative of 3 cultures of E13 NPCS). C, The CRAC channel inhibitor BTP-2 attenuated SOCE in NPCS. NPCS were pretreated with BTP-2 (1 $\mu \mathrm{M})$ for $5 \mathrm{~h} \mathrm{before} \mathrm{Ca}^{2+}$ imaging (P2; ${ }^{* * *} p<0.0012$-sample unpaired $t$ test, $n=23-29$ cells, representative of 2 cultures of P2 NP(s).

\section{Suppressing STIM1 and Orail expression/function diminishes SOCE in NPCs}

Prototypic CRAC channels are a two-component system composed of STIM1, the ER $\mathrm{Ca}^{2+}$ sensor, and Orail, the poreforming protein (Lewis, 2011). mRNA and protein expression studies indicate that STIM1 and Orail are widely expressed in many organ systems, including the nervous system (Gross et al., 2007; Gwack et al., 2007; Klejman et al., 2009; Skibinska-Kijek et al., 2009), but whether these proteins are expressed and functional in the neurogenic regions of the brain is unclear. We therefore examined the contribution of STIM1 and Orail for SOCE in NPCs using several approaches. In one approach, we suppressed expression of STIM1 and/or Orail using siRNA knock down. Knock down of STIM1 and Orail significantly reduced SOCE in NPCs, reducing the rate of $\mathrm{Ca}^{2+}$ influx after re-addition of extracellular $\mathrm{Ca}^{2+}$ from $3.68 \pm 0.51$ to $\sim 1 \mathrm{nM} / \mathrm{s}$ in siSTIM1- and siOrail-treated cells (Fig. $2 A, B$ ). In a second approach, analysis of protein expression by Western blot revealed the presence of STIM1 and Orail that was sensitive to siRNA mediated knock down (Fig. 2C). For Orail, protein expression was observed as a series of bands of $\sim 25 \mathrm{kDa}$, as expected from the glycosylation of Orail and the presence of an alternate translational initiation site in the N terminus (McNally et al., 2009; Fukushima et al., 2012). Finally, overexpression of a dominant-negative Orail mutant, E106AOrail, strongly inhibited SOCE (from $4.73 \pm 1.11 \mathrm{~nm} / \mathrm{s}$ in control cells to $0.09 \pm 0.03 \mathrm{~nm} / \mathrm{s}$ in E106AOrail-expressing NPCs; $p<0.0001$; data not shown). Together, these studies indicate that NPCs express store-operated $\mathrm{Ca}^{2+}$ entry that is encoded by the canonical CRAC channel proteins STIM1 and Orail.

The residual SOCE in siRNA-treated cells could be due either to incomplete suppression of STIM1 and Orail (Fig. $2 A-D$ ) or to contribution from other STIM and Orai paralogs (STIM2/Orai2/ Orai3). To determine whether the residual SOCE is due to incomplete suppression of STIM1 and Orail knock down, we examined SOCE in NPCs derived from transgenic mice lacking functional STIM1 or Orail. In one set of studies, we examined NPCs isolated from Orail ${ }^{\mathrm{R} 93 \mathrm{~W} / \mathrm{R} 93 \mathrm{~W}}$ knock-in mice. These mice contain the loss-of-function R93W mutation in Orai1, equivalent to the R91W mutation described in human SCID patients (Feske et al., 2006; Bergmeier et al., 2009). Compared with Orail $^{+/+}$NPCs, SOCE was significantly suppressed in Orai1 ${ }^{\mathrm{R} 93 \mathrm{~W} /+}$ NPCs and abolished in Orai1 ${ }^{\mathrm{R} 93 \mathrm{~W} / \mathrm{R} 93 \mathrm{~W}}$ NPCs (Fig. $2 E, H, I)$. Likewise, germline deletion of one or both alleles of
Orail resulted in suppression or complete loss of SOCE in embryonic NPCs (Fig. 2F,H,I). Qualitatively similar results were observed in STIM1 KO mice (Fig. 2G-I). The extent of SOCE loss exhibited a clear gene dosage effect in which the peak amplitude and the initial rate of $\left[\mathrm{Ca}^{2+}\right]_{i}$ entry after extracellular $\mathrm{Ca}^{2+}$ re-addition were attenuated to a much greater extent in the homozygous mice (Orail ${ }^{\mathrm{R} 93 \mathrm{~W} / \mathrm{R} 93 \mathrm{~W}}$, Orail ${ }^{-1-}$, and STIM1 ${ }^{-1-}$ ) compared with heterozygous mice (Orai1 ${ }^{\mathrm{R} 93 \mathrm{~W} /+}$, Orai ${ }^{+/-}$, and STIM1 $\left.{ }^{+1-}\right)$. Collectively, these results indicate that STIM1 and Orail are essential for SOCE in embryonic NPCs.

Emerging evidence indicates that $\mathrm{Ca}^{2+}$ signals regulate neurogenesis and gene transcription, not only in embryonic NPCs, but also in adult NPCs (Deisseroth et al., 2004; Pathania et al., 2010). We therefore sought to examine the molecular properties of SOCE in adult NPCs. However, these experiments were complicated by the high postnatal mortality of transgenic mice lacking STIM1 or Orail (Gwack et al., 2008; Oh-Hora et al., 2008) or expressing the loss-of-function OrailR93W mutant protein (Bergmeier et al., 2009), with most mice dying in the first few hours after birth. Therefore, we generated a conditional brainspecific KO of Orail by crossing Orai ${ }^{\mathrm{fl} / \mathrm{fl}}$ mice to transgenic mice expressing Cre-recombinase under the nestin promoter. As described previously, nestin-Cre deleter mice are widely used to generate brain-specific deletion of target genes (Bates et al., 1999; Groszer et al., 2001). PCR analysis of genomic DNA isolated from various tissues showed deletion of Orail specifically in brain tissue derived from Orai ${ }^{\mathrm{f} / \mathrm{fl}: \mathrm{Nes}-\mathrm{Cre}}$ and Orai ${ }^{\mathrm{f} / /+ \text { :Nes-Cre }}$ mice, but not in the control mice (Fig. 3B). Conditional deletion of Orail in the brain did not cause the perinatal lethality that is observed in whole animal germline KOs of Orai1, enabling us to investigate $\mathrm{Ca}^{2+}$ influx mechanisms in adult brain NPCs.

These studies revealed that SOCE in adult NPCs was markedly diminished in cells from Orail ${ }^{\mathrm{fl} /}-$ and Orai $\mathrm{f}^{\mathrm{fl} /- \text { :Nes-Cre mice }}$ compared with WT littermates (Fig. 3C-E). Further, as seen in embryonic mice, a haplotype insufficiency phenotype is clearly evident, with the Orai ${ }^{\mathrm{f} / \text { - }: \text { Nes-Cre }}$ mice exhibiting markedly diminished $\mathrm{Ca}^{2+}$ entry after re-addition of extracellular $\mathrm{Ca}^{2+}$ compared with heterozygous Orail ${ }^{\mathrm{fl} /-}$ mice $(\mathrm{Fig} 3 C-E)$. In contrast to embryonic mice, however, NPCs from adult mice showed a very small residual $\mathrm{Ca}^{2+}$ influx after extracellular $\mathrm{Ca}^{2+}$ readdition. We did not further investigate the molecular identity of this small residual $\mathrm{Ca}^{2+}$ entry, but did find that it was sensitive to blockade by low concentrations of $\mathrm{La}^{3+}(2 \mu \mathrm{M}$; Fig. $3 C$ ), suggesting that it also arises from CRAC channels, albeit of a different 
A P2 NPCs

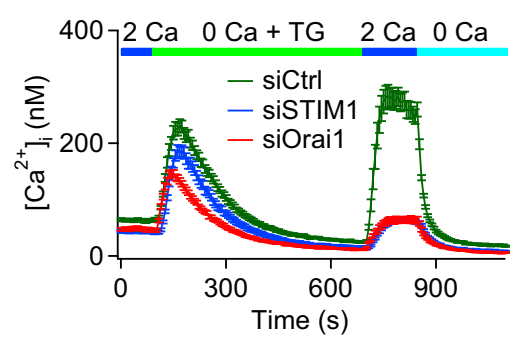

E E18 NPCs

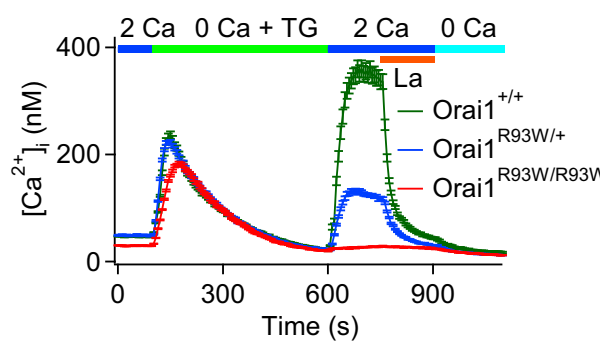

H E18 NPCs

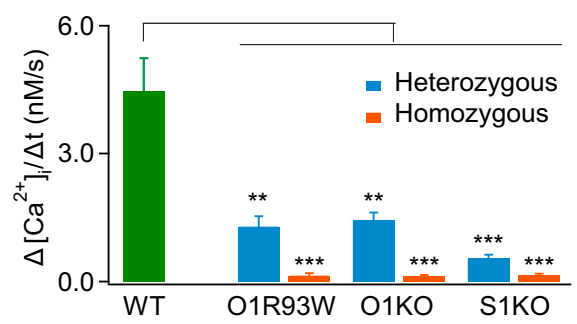

B P2 NPCs C E13 NPCs

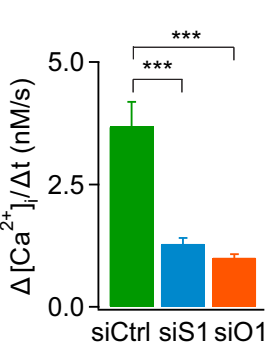

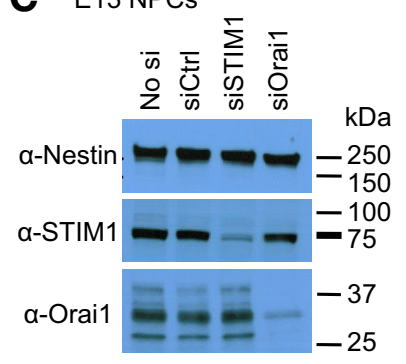

D E13 and P2 NPCs
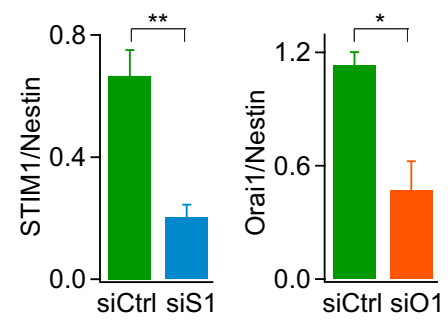

F E18 NPCs

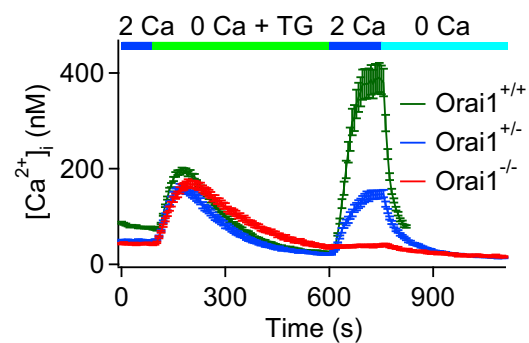

I E18 NPCs
G E18 NPCs

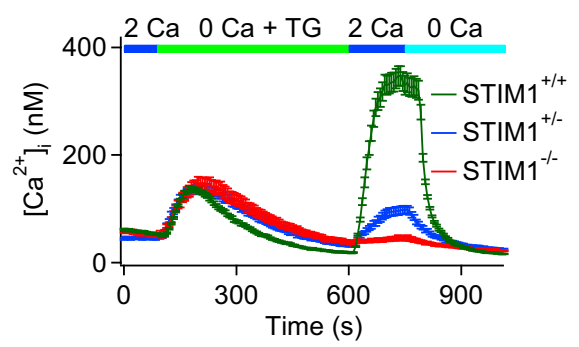

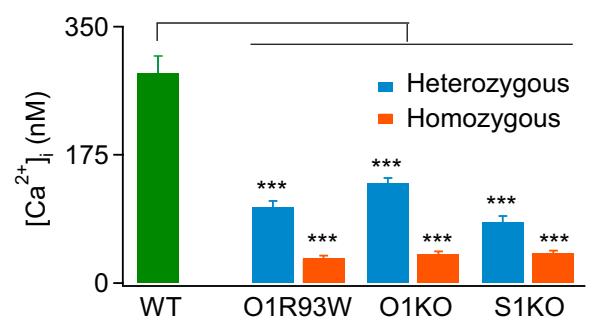

Figure 2. STIM1 and Orai1 are essential for SOCE in embryonic and neonatal NPCS. $\boldsymbol{A}, \boldsymbol{B}, \mathrm{SOCE}$ is significantly diminished in NPCs treated with siSTIM1 and siOrai1 (P2; ${ }^{*} p<0.0001$ determined by one-way ANOVA followed by 2-sample unpaired $t$ test, $n=35-82$ cells, representative of 3 cultures). C, Western blots showing expression of STIM1 and Orai 1 in E13 NPCs and after knock down of these proteins by treatment with siRNA. Nestin was used as the loading control. D, Summary graphs showing relative expression of STIM1 and 0 rai1 in NPCS after suppression of these molecules (E13 and P2; ${ }^{* *} p<0.01,{ }^{*} p<0.05$, unpaired $t$ test, $n=3$ blots from 2 cultures). $E-G$, SOCE is abolished in NPCs derived from homozygous 0 rai ${ }^{\text {R93W/R93W }}$, Orai ${ }^{-1-}$, and STIM1 ${ }^{-1-}$ mice and significantly diminished in heterozygous $0 \mathrm{rai}^{\mathrm{R} 93 \mathrm{~W} /+}, 0$ rai ${ }^{+/-}$, and STIM1 ${ }^{-/-} \mathrm{NPCS}$. $\boldsymbol{H}$, Summary of the rate of $\mathrm{Ca}^{2+}$ entry after re-addition of extracellular $\mathrm{Ca}{ }^{2+}$ in the indicated transgenic mice. $\mathrm{Ca}^{2+}$ influx rates were estimated by measuring the initial slope of $\mathrm{Ca}^{2+}$ entry over $30 \mathrm{~s}$ (E18; $p<0.0001$, one-way ANOVA followed by post hoc 2 -sample unpaired $t$ tests between WT and mutant pairs, ${ }^{* *} p<0.001,{ }^{* *} p<0.01$, average data from $77-852$ cells from $4-13$ experiments, from $2-11$ mice). $I$, Summary of the average [Ca $\left.{ }^{2+}\right]_{\mathrm{i}}$ measured $120 \mathrm{~s}$ after addition of extracellular $\mathrm{Ca}^{2+}$ (E18; $p$-values determined as in $\boldsymbol{H} ;\left[\mathrm{Ca}^{2+}\right]_{i}$ was averaged over a $30 \mathrm{~s}$ duration).

molecular composition (possibly Orai2 or Orai3). Together, these studies indicate that SOCE in both embryonic and adult NPCs is encoded predominantly by the canonical CRAC channel proteins STIM1 and Orail.

\section{Maturation of NPCs regulates SOCE}

As progenitor cells develop and differentiate into mature neurons and glia, the ion channel repertoire of these cells is modified through increased expression of voltage- and ligand-activated conductances to enhance membrane excitability (Yasuda and Adams, 2010). To explore how CRAC channel expression and function is altered during this process, we next examined SOCE and Orail expression in subpopulations of NPCs. A key attribute of NSCs/NPCs is the expression of the filamentous proteins nestin and GFAP (Lendahl et al., 1990; Doetsch et al., 1999). Immunostaining revealed that $78 \pm 4 \%$ of NSCs/NPCs grown as neurospheres also expressed the intermediate filament nestin (Fig. 4A). Because the majority of cells grown as neurospheres $(>90 \%)$ also displayed SOCE, this result indicates that there is high overlap between the progenitor marker (nestin) and func- tional presence of SOCE. Moreover, a fraction $(\sim 28 \pm 4 \%)$ of the cultured NPCs also showed expression of GFAP (Fig. 4B). GFAP is commonly associated with differentiated astrocytes, but is also a marker for proliferating NSCs/NPCs, especially in neurospheres cultured from postnatal and adult forebrains (Imura et al., 2003; Bonaguidi et al., 2005). Importantly, immunolabeling for Orail and GFAP revealed that all $(100 \pm 0 \%) \mathrm{GFAP}^{+}$cells were also positive for Orail (Fig. $4 B$ and data not shown). Therefore, these results reaffirm that the machinery for SOCE is strongly expressed in nestin- and GFAP-expressing NSC/NPCs.

NPCs derived from neurospheres differentiate into neuroblasts or glia and, at the neuroblast stage, they express the microtubule-associated protein doublecortin (DCX). To determine how SOCE changes during maturation to the neuronal phenotype, we examined SOCE in NPCs derived from DCX-EGFP reporter mice. In these mice, EGFP is expressed under the control of the DCX promoter, providing a method to conveniently track the cells normally expressing DCX (Bhattacharyya et al., 2008). These experiments indicated that SOCE is strongly downregulated in DCX-EGFP ${ }^{+}$cells compared with DCX-EGFP ${ }^{-}$cells 
A
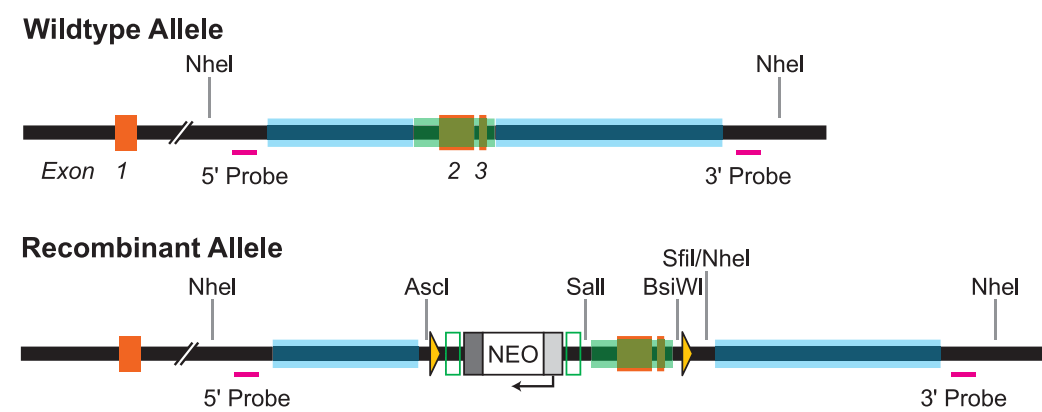

B Adult NPCs

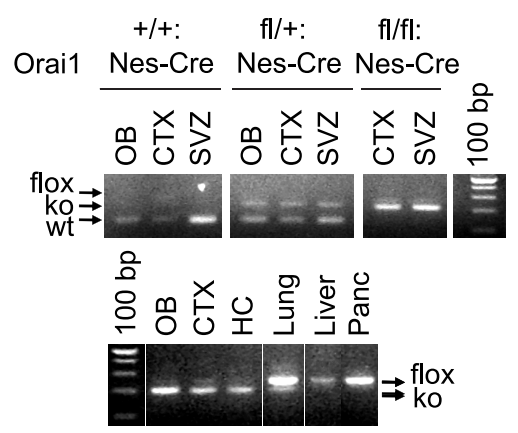

Orail floxed Allele
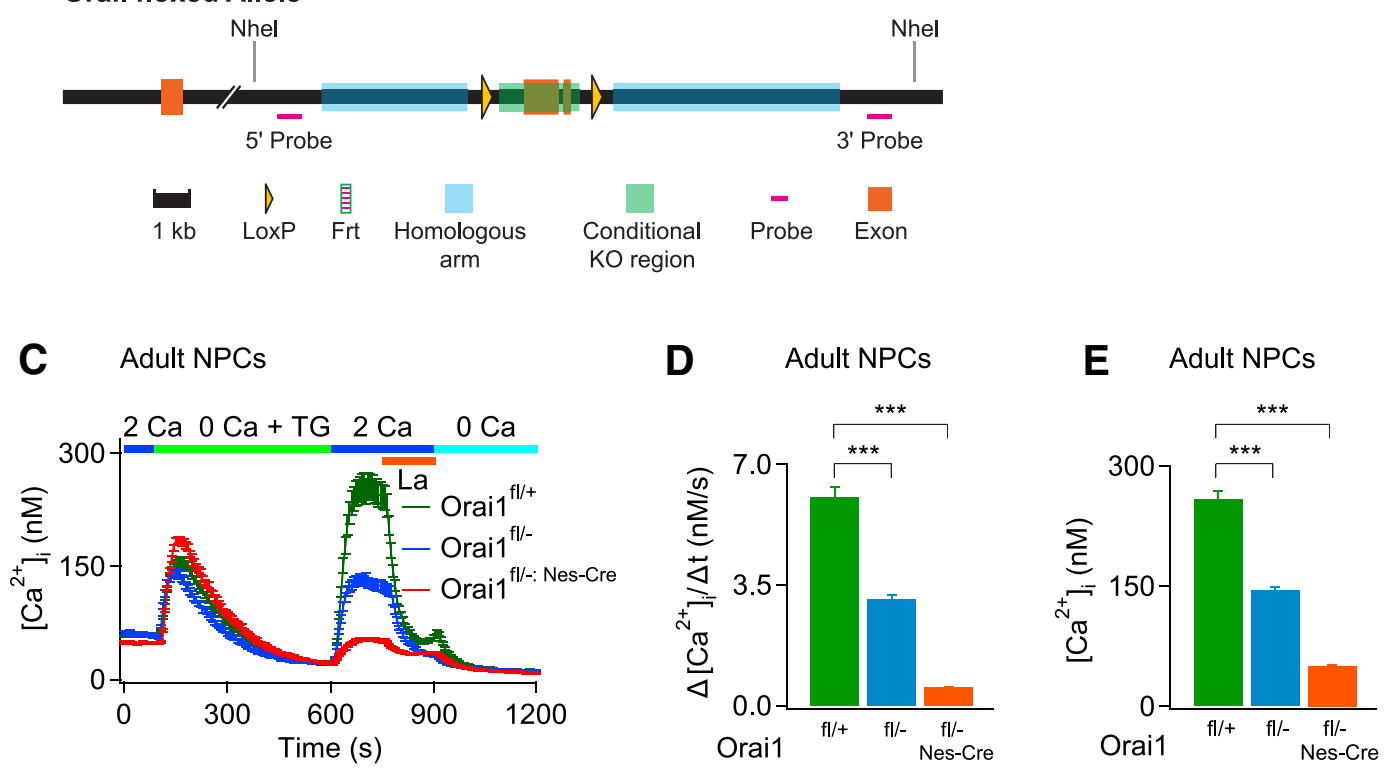

Figure 3. Orai1 is critical for SOCE in adult NPCS. A, Schematic of the targeting strategy for conditional deletion of Orai1. The Orai1-targeting construct inserted an FRT2-PGK neocassette flanked by LoxP sites around exons 2 and 3 into the WT locus. The genomic organization of that insertion is shown as the recombinant allele. PGKNeo was removed through Flp electroporation of ES cells verified for the insertion by PCR and Southern blot and is shown as the final floxed allele after recombination. Deletion of exons 2 and 3 removes the entire coding region of Orai1. $B, P C R$ of genomic DNA isolated from various tissues in Orai ${ }^{+/+ \text {:Nes-Cre }}$, Orai $1^{\text {fl/+:Nes-Cre }}$, and Orai $1^{\text {fl/f:Nes-Cre }}$ mice showing deletion of Orai in brain tissue (top). Bottom, Deletion of Orai1 specifically in brain tissue in the Orai1 ${ }^{\text {flff: }: \text { Nes-Cre }}$ mouse. OB, Olfactory bulb; (TX, cortex; HC, hippocampus; Panc, pancreas (20-week-old mice representative of 2 PCR experiments from 2 sets of mice). $C$, SOCE is significantly diminished in adult (24-week-old) Orai $1^{\mathrm{flffl:Nes}-\mathrm{Cre}} \mathrm{NPCs}$. $\mathrm{Ca}^{2+}{ }^{+}$influx rates $(\boldsymbol{D})$ and $\left[\mathrm{Ca}^{2+}\right] \mathrm{i}(\boldsymbol{E})$ are strongly attenuated after re-addition of external $\mathrm{Ca}^{2+}\left(12\right.$ - to 22 -week-old mice; ${ }^{* * *} p<0.001$, unpaired $t$ test, $n=122-237$ cells, 3-8 experiments).

(Fig. $4 F, G$ ). To better understand the mechanistic basis of this downregulation, we costained cultured NPCs for DCX and Orai1 by immunocytochemistry (Fig. $4 D, E$ ). These experiments revealed that, in contrast to the $100 \%$ labeling of Orail seen in $\mathrm{GFAP}^{+}$cells, only $33 \pm 5 \%$ of the $\mathrm{DCX}^{+}$cells costained for Orail (Fig. $4 D$ and data not shown). Therefore, the decrease in SOCE seen in the DCXEGFP NPCs is likely related to the reduced expression of Orail. Together, these results suggest that the SOCE is regulated by the maturation state of NPCs and is specifically downregulated in cells expressing the neuroblast marker DCX due to diminished expression of the CRAC channel protein Orail.

\section{EGF and muscarine activate CRAC channels in NPCs}

CRAC channels are typically activated after stimulation of cell surface receptors coupled to the phospholipase $\mathrm{C}$ signaling and subsequent depletion of intracellular $\mathrm{Ca}^{2+}$ stores through the generation of inositol-1,4,5-trisphosphate (IP 3 ; Hogan et al., 2010; Lewis, 2011). To determine whether CRAC channels contribute to the effector responses of growth factors and neurotransmitters linked to PLC signaling in NPCs, we tested several agonists of cell surface receptors for their ability to stimulate CRAC channel activation in NPCs. We

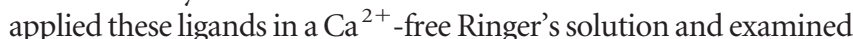
SOCE after re-addition of external $\mathrm{Ca}^{2+}$. This screen revealed that EGF and muscarine are strong activators of SOCE in NPCs (Table 1). EGF is a potent mitogen that regulates proliferation of a wide variety of cell types (Prenzel et al., 2001) and is essential for the proliferation of NPCs (Reynolds et al., 1992). EGF acts via tyrosine kinase receptors, leading to stimulation of phospholipase $\mathrm{C}$ and $\mathrm{IP}_{3}$ signaling, which in turn would be expected to deplete $\mathrm{ER} \mathrm{Ca}^{2+}$ stores (Ullrich and Schlessinger, 1990). Likewise, cholinergic activation of muscarinic ACh receptors (mAChRs) mobilizes $\mathrm{Ca}^{2+}$ signaling in many cells (Felder, 1995). mAChR subunits are expressed in the neurogenic regions of rodent brains (Ma et al., 2000; Kaneko et al., 2006) and cholinergic signaling has been implicated in many aspects of neurogenesis (Resende and Adhikari, 2009).

Administration of EGF $(100 \mathrm{ng} / \mathrm{ml})$ in a $\mathrm{Ca}^{2+}$-free solution produced a transient $\mathrm{Ca}^{2+}$ elevation suggestive of $\mathrm{Ca}^{2+}$ release from intracellular stores (Fig. 5A). Subsequent re-addition of extracellular $\mathrm{Ca}^{2+}$ elicited a significant $\mathrm{Ca}^{2+}$ elevation that was blocked by $\mathrm{La}^{3}(2 \mu \mathrm{M}$, Fig. $5 \mathrm{~A})$. In a variation of this test, appli- 
A E13 NPCs

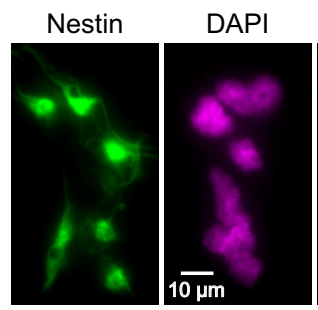

B Orai $^{\mathrm{fl} / f l}$, Adult NPCs

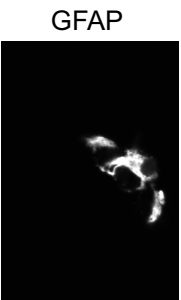

Orai1

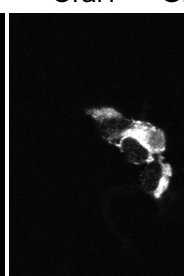

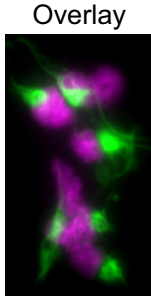

GFAP/Orai1/DAPI

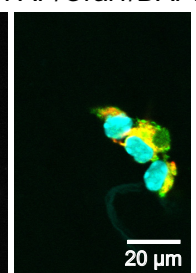

C Orai $1^{\mathrm{fl} / \text {-: Nes-Cre }}$, Adult NPCs

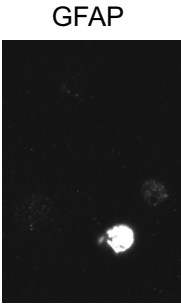

Orai1

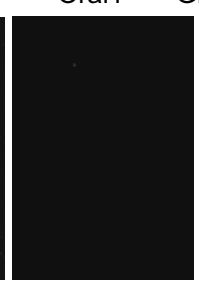

FAP/Orai1/DAP

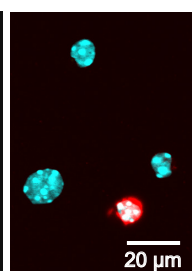

D Orai $^{\mathrm{fl} / \mathrm{fl}}$, Adult NPCs

$$
\text { DCX }
$$

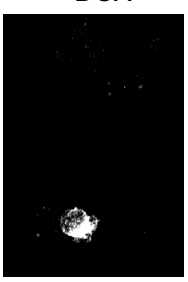

Orai1

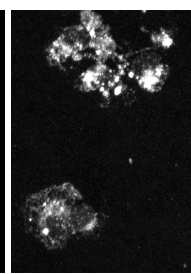

DCX/Orai1/DAPI

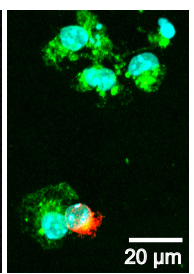

E Orai1 $^{\text {fll/: Nes-Cre }}$, Adult NPCs

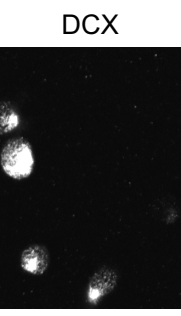

Orai1

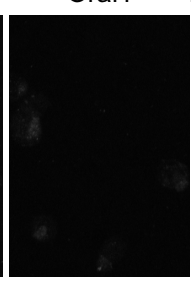

F

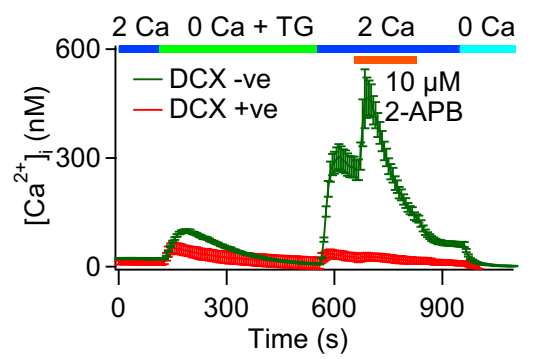

G E15 NPCs

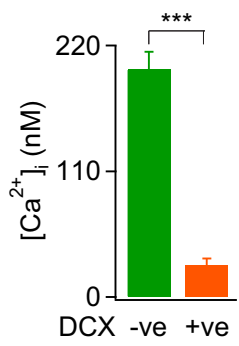

H E15 NPCs

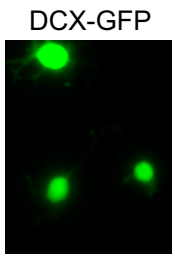

DIC

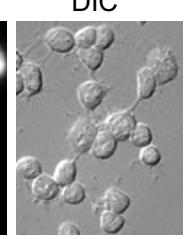

Figure 4. NPC maturation regulates SOCE. A, Neurospheres cultured from E13 NPCs express the progenitor marker nestin. Cells were fixed and immunolabeled for nestin $\sim 16 \mathrm{~h}$ after plating. Nuclei were labeled using DAPI. B, Costaining of NPCs with GFAP and Orai1. Cells were imaged at the coverslip interface (images show the cell footprint). NPCs were cultured from P21 mice. C, Orai1 labeling is absent in the Orai $1^{\mathrm{fl} / \text {-:Nes-Cre }}$ mice, confirming the deletion of Orai1 in these mice (P21) D, Costaining of NPCs for the neuroblast marker DCX and for Orai1. $E$, Staining of NPCs from Orai $1^{\mathrm{fl}-\text {-:Nes-Cre }}$ mice for DCX and Orai1. No Orai1 labeling is seen in the Orai ${ }^{\mathrm{fl} /- \text {-Nes-Cre }}$ mice, as expected from the genetic ablation of Orai1. $F$, SOCE is diminished in NPCS expressing DCX-GFP compared with GFP ${ }^{-}$cells. NPCS were isolated from DCX-GFP mice and $\left[\mathrm{Ca}^{2+}\right]$ i was measured using fura-2 as in Figure 1. G, Summary of SOCE amplitude after re-addition of extracellular $\mathrm{Ca}^{2+}$ (E15 mice; unpaired $t$ test, ${ }^{* * *} p<0.001, n=13-143$ cells, representative of 3 experiments from 2 cultures). $\boldsymbol{H}$, Images of NPCs expressing DCX-GFP loaded with fura-2. The fura- 2 signal is at the 380 nm excitation wavelength. DIC, Dfferential interference contrast.

Table 1. Agonists stimulating SOCE in NPCS

\begin{tabular}{llc}
\hline Ligand & Cells responding (\%) & Cells tested (no.) \\
\hline EGF & 65.3 & 754 \\
Acetylcholine & 49.5 & 101 \\
Muscarine & 51.7 & 267 \\
L-glutamate & 60.2 & 266 \\
SDF-1 $\alpha$ & 23.1 & 368 \\
UTP & 6.5 & 77 \\
Caffeine & 5.9 & 34 \\
Wnt-5 $\alpha$ & 4.7 & 107 \\
Baclofen & 2.5 & 40 \\
GABA & 1.7 & 290 \\
BDNF & 1.0 & 196 \\
BMP & 0.0 & 31 \\
FGF & 0.0 & 218 \\
\hline
\end{tabular}

Wild-type NPCs derived from embryonic (E12, E13, E15, E18), neonatal (P0-P3), or adult ( $~ 8$ weeks old) mice were treated with the indicated ligands in a $\mathrm{Ca}^{2+}$-free Ringer's solution. Extracellular $\mathrm{Ca}^{2+}$ was then restored $(2 \mathrm{~mm})$ and the amplitude of the $\left[\mathrm{Ca}^{2+}\right]$ i was examined. Cells were considered responders if the $\left[\mathrm{Ca}^{2+}\right]$ i elevation was $>2 \times$ SEM above the resting $\left[\mathrm{Ca}^{2+}\right]$ i. cation of EGF in the presence of extracellular $\mathrm{Ca}^{2+}$ produced a biphasic $\mathrm{Ca}^{2+}$ signal, the sustained component of which was eliminated in Orail ${ }^{\text {fl/fl:nes-CRE }}$ NPCs (Fig. $5 B, C$ ). These results indicate that EGF mobilizes $\mathrm{Ca}^{2+}$ elevations in NPCs through release of intracellular $\mathrm{Ca}^{2+}$ stores followed by activation of SOCE via Orail channels. Similarly, a saturating concentration of acetylcholine $(300 \mu \mathrm{M})$ triggered $\mathrm{Ca}^{2+}$ signals consistent with SOCE (Fig. 5D). The ACh-induced $\mathrm{Ca}^{2+}$ signal was blocked by low concentration of $\mathrm{La}^{3+}(2 \mu \mathrm{M})$ and the mAChR antagonist atropine, suggesting involvement of metabotropic $\mathrm{ACh}$ receptors (Fig. 5D). Direct tests with muscarine (50 $\mu \mathrm{M})$, a selective agonist of metabotropic ACh receptors, indicated that $\mathrm{mAChR}$ activation causes robust SOCE (Fig. 5E). Consistent with an essential role for Orail in this pathway, the sustained $\mathrm{Ca}^{2+}$ elevations caused by muscarine were diminished in the heterozygous Orail ${ }^{\mathrm{R} 93 \mathrm{~W} /+}$ NPCs and eliminated in the Orail ${ }^{\mathrm{R} 93 \mathrm{~W} / \mathrm{R} 93 \mathrm{~W}}$ NPCs (Fig. $5 F$ ).

Interestingly, unlike cells derived from WT mice, which exhibited only sustained $\mathrm{Ca}^{2+}$ signals in response to muscarine 
A Adult NPCs

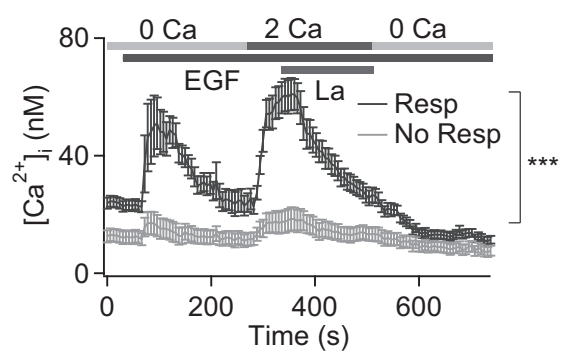

D Adult NPCs

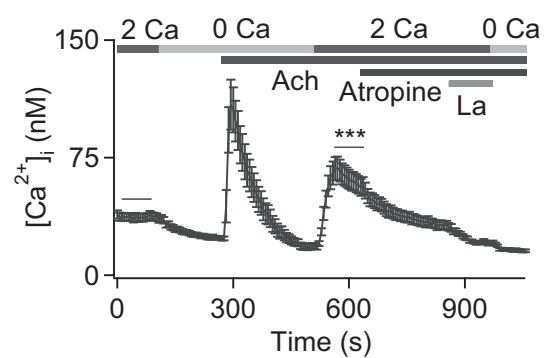

\section{B Adult NPCs}

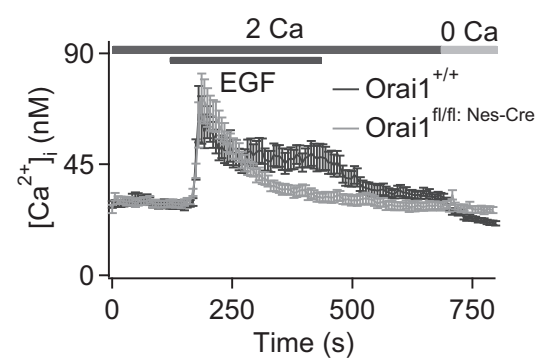

E Adult NPCs

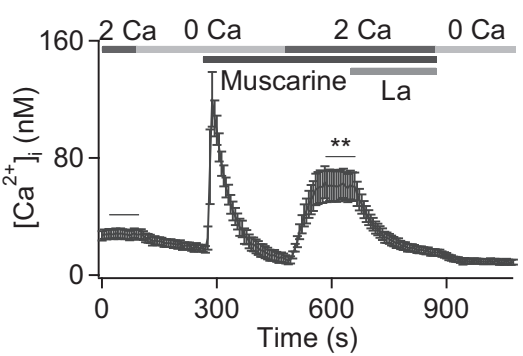

C Adult NPCs

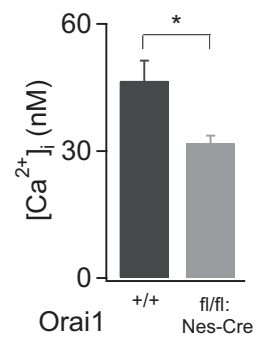

F PONPCs

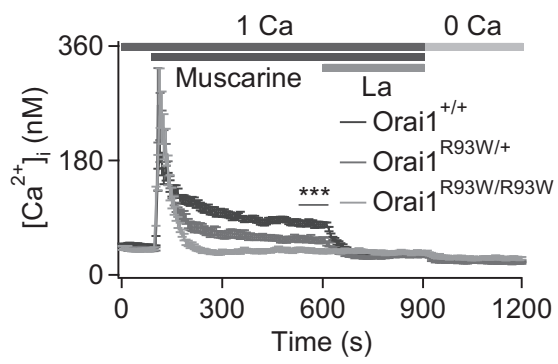

G PONPCs
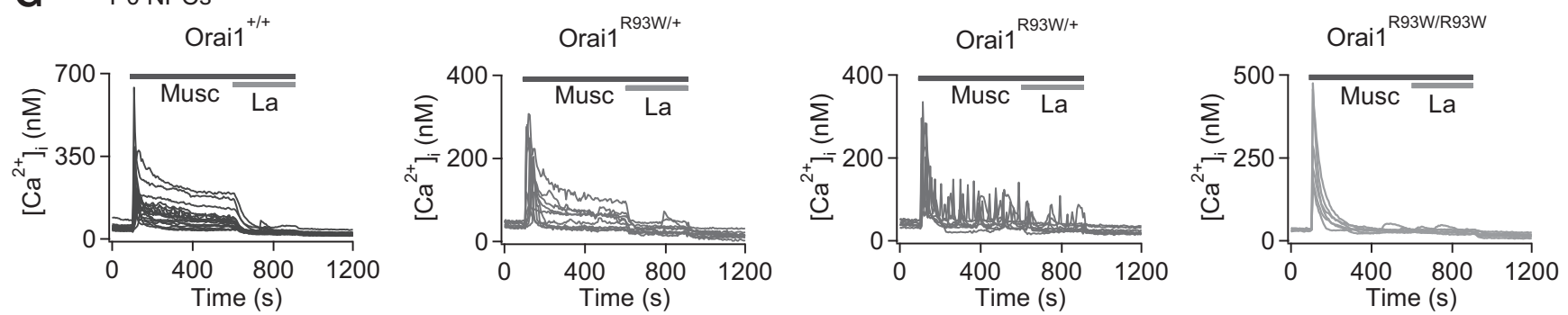

Figure 5. Stimulation of EGF and muscarinic ACh receptors activates SOCE in NPCS. $A$, Application of EGF ( $100 \mathrm{ng} / \mathrm{ml})$ in a Ca ${ }^{2+}$-free Ringer's solution followed by re-addition of extracellular Ca ${ }^{2+}$ elicits $\left[\mathrm{Ca}^{2+}\right]_{\mathrm{i}}$ elevation that is blocked by $\mathrm{La}^{3+}(2 \mu \mathrm{M})$. The two traces show averages of cells that responded with a rise in $\left[\mathrm{Ca}^{2+}\right]$ iand thosethat failed to respond after application of EGF.P1 mice, $P$-values determined by 2-sample unpaired $t$ test, $n=17 / 29$ cells responded to EGF (Resp), while the remainder of the cells did not show increases in $\left[\mathrm{Ca}^{2+}\right]$ i (No Resp). ${ }^{* * *} p<0.001$, unpaired $t$ test, 17/29 cells responded to EGF (Resp). $\boldsymbol{B}$, Administration of EGF (100 ng/ml) in the presence of extracellular $\mathrm{Ca}^{2+}$ produces a biphasic $\left[\mathrm{Ca}^{2+}\right]_{\mathrm{i}}$ elevation. C, The sustained component of the EGF-stimulated $\mathrm{Ca}{ }^{2+}$ signal is eliminated in Orai1-deficient (Orai1 ${ }^{\mathrm{f} / \mathrm{ft}: \text { Nes-Cre }}$ ) NPCs (adult 8 weeks old, ${ }^{*} p<0.05$, unpaired $t$ test, $n=13-14$ cells for each condition, representative of 2 experiments). D, Application of ACh (300 $\mu \mathrm{M}$ ) in a $\mathrm{Ca}^{2+}$-free Ringer's solution stimulates a transient $\left[\mathrm{Ca}^{2+}\right]_{i}$ elevation. Re-addition of extracellular $\mathrm{Ca}^{2+}$ produces $\mathrm{Ca}^{2+}$ entry that is inhibited by atropine $(20 \mathrm{nM})$ and $\mathrm{La}^{3+}(2 \mu \mathrm{M})$. Methyllycaconitine citrate (MLA) and dihydro- $\beta$-erythroidine (DHBE) were used in all solutions to blocknAChR subunits (8-week-old NPCs, ${ }^{* * *} p<0.001$ determined by paired ttests, $n=26 / 33$ cells responded to ACh). $\boldsymbol{E}$, Administration of muscarine $(50 \mu \mathrm{M})$ in $\mathrm{Ca}^{2+}$-free solution triggers $\mathrm{ERCa}^{2+}$ store release. Subsequent re-addition of extracellular $\mathrm{Ca}^{2+}$ causes $\mathrm{Ca}^{2+}$ influx that is inhibited by $\mathrm{La}^{3+}\left(2 \mu \mathrm{m}\right.$; adult 8 weeks old, ${ }^{* * *} p<0.001$, 2-tailed paired $t$ test, $n=10 / 15$ cells responded to muscarine). $\boldsymbol{F}$, Application of muscarine $(50 \mu \mathrm{M})$ in the standard extracellular Ringer's solution produces a biphasic $\left[\mathrm{Ca}^{2+}\right]_{\mathrm{i}}$ elevation. The sustained phase of the $\left[\mathrm{Ca}^{2+}\right]_{\mathrm{i}}$ elevation is suppressed in Orai ${ }^{\mathrm{R} 93 \mathrm{~W} /{ }^{+}} \mathrm{NPC}$ and abolished in Orai ${ }^{\mathrm{R} 93 \mathrm{~W} / \mathrm{R} 93 \mathrm{~W}} \mathrm{NPC}$. (PO, one-way ANOVA, $p<0.0001$, followed by unpaired $t$ test between WT and each test condition, ${ }^{* * *} p<$ $0.001 n=10-21$ cells, representative of 5 experiments from 2 cultures). G, Single-cell $\mathrm{Ca}^{2+}$ responses after application of $200 \mu$ m muscarine. $\mathrm{Ca}^{2+}$ oscillations are seen in $\sim 50 \%$ of the 0 rai ${ }^{\mathrm{R} 93 \mathrm{~W} /+}$ NPCs that responded to muscarine $(\mathrm{P} 0, n=16-18$ cells for each condition).

stimulation, a significant fraction of the responders in the heterozygous Orail ${ }^{\mathrm{R} 93 \mathrm{~W} /+}$ NPCs exhibited $\mathrm{Ca}^{2+}$ oscillations that were not present in the homozygous Orai1 ${ }^{\mathrm{R} 93 \mathrm{~W} / \mathrm{R} 93 \mathrm{~W}}$ NPCs (Fig. 5G). Previous studies have shown that the strength and specificity of cellular effector responses, including gene transcription, differs between oscillatory and sustained $\mathrm{Ca}^{2+}$ signals (Dolmetsch et al., 1998). Therefore, these results raise the possibility that the $\mathrm{Ca}^{2+}$ oscillations caused by submaximal $\mathrm{Ca}^{2+}$ entry through CRAC channels stimulate cellular functions apart from sustained signals elicited by maximal CRAC channel activation. Together, these results indicate that CRAC channels are activated by both mitogens and neurotransmitters in NPCs.

\section{CRAC channels activate NFAT-dependent gene expression in NPCs}

A key mechanism through which $\mathrm{Ca}^{2+}$ signals regulate downstream effector functions, including cell growth and differentia- tion, is through the NFAT family of transcription factors (Crabtree and Olson, 2002; Hogan et al., 2003). NFAT proteins are normally phosphorylated and reside primarily in the cytoplasm at rest. However, $\mathrm{Ca}^{2+}$ elevations trigger the dephosphorylation of NFAT through the phosphatase calcineurin, causing NFAT to translocate into the nucleus, where it can initiate gene transcription in diverse cell types (Crabtree and Olson, 2002; Hogan et al., 2003). In NPCs, the physiological role of calcineurin/NFAT signaling is presently unknown. However, the central role of NFAT signaling for effector function in many nonexcitable cells led us to consider whether NPCs exhibit NFAT activity and if CRAC channels regulate its activity. We approached this question in two ways. First, we examined the nuclear translocation of exogenously transfected GFP-NFAT1. Activation of SOCE by depletion of $\mathrm{ER} \mathrm{Ca}^{2+}$ stores with $1 \mu \mathrm{M}$ TG resulted in nuclear translocation of GFP-NFAT1 in a majority of NPCs (Fig. $6 A, B)$. Nuclear translocation of GFP-NFAT1 was significantly 
A E13 NPCs

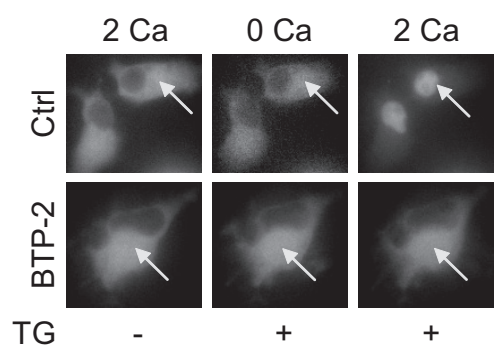

B

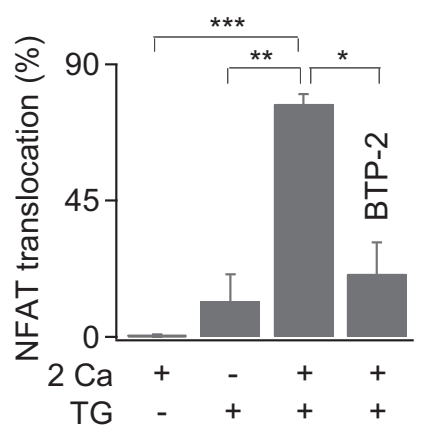

E E18 NPCs

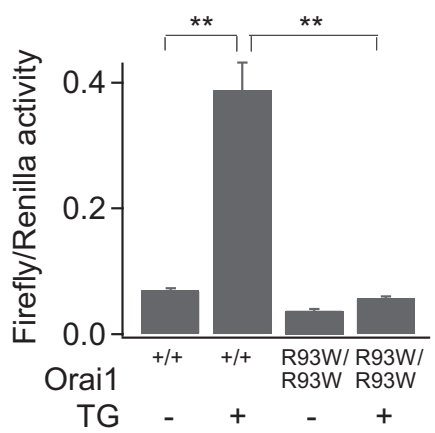

H E13 NPCs

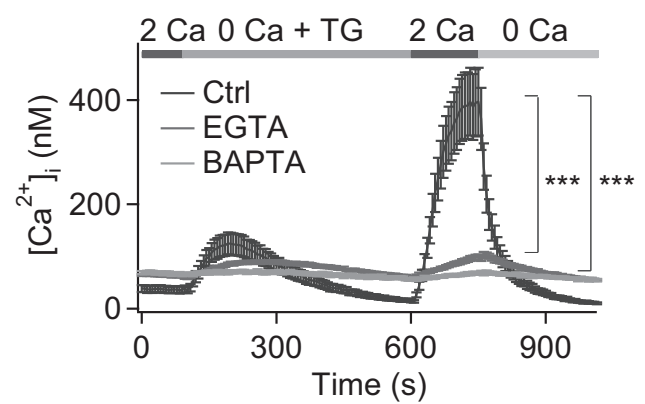

Time (s)
C E13 NPCs

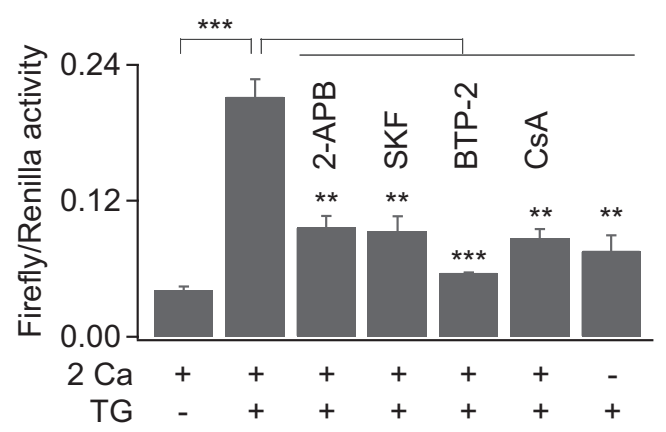

F E13 NPCs

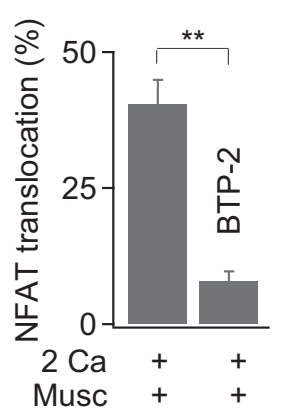

G

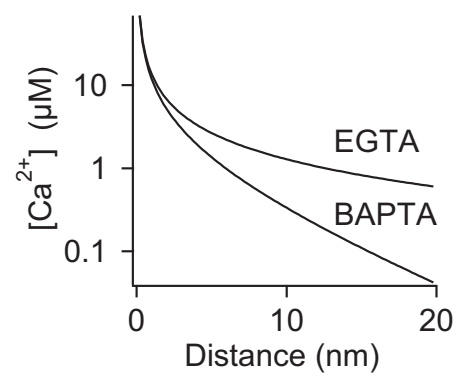

I E13 and E14 NPCs

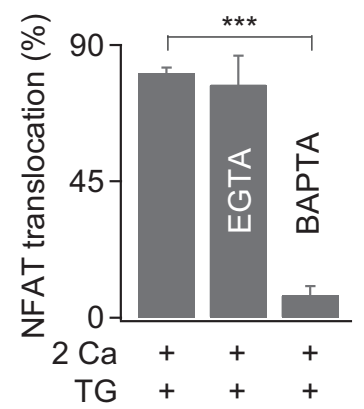

Figure 6. CRAC channels activate NFAT-dependent gene expression in NPCS. A, NPCs were nucleofected with GFP-NFAT1 and imaged $24-48 \mathrm{~h}$ later. Images were acquired in $2 \mathrm{~mm}$ extracellular $\mathrm{Ca}^{2+}, 15 \mathrm{~min}$ after application of $1 \mu \mathrm{M} \mathrm{TG}$, in a $\mathrm{Ca}^{2+}$-free solution, and $15 \mathrm{~min}$ after re-addition of $2 \mathrm{~mm} \mathrm{Ca}^{2+}$. Where indicated, BTP-2 (1 $\left.\mu \mathrm{m}\right)$ was applied for 3-5 h before the experiment. $\boldsymbol{B}$, Summary of the percentage of cells showing nuclear translocation of GFP-NFAT1. (E13 and P2; one-way ANOVA, $p=0.0003$, followed by unpaired $t$ test between indicated test conditions, ${ }^{*} p<$ $0.05,{ }^{* *} p<0.01,{ }^{* * *} p<0.001, n=93-133$ cells from 3-4 experiments). C, NFAT luciferase activity stimulated by depletion of ER Ca ${ }^{2+}$ stores is significantly suppressed by pretreatment with the CRAC channel inhibitors 2-APB $(50 \mu \mathrm{M})$, SKF96365 $(20 \mu \mathrm{M})$, and BTP-2 $(0.5 \mu \mathrm{m})$ in the presence of low external $\mathrm{Ca}^{2+}$ and by cyclosporine A $(1 \mu \mathrm{M}$; E13; one-way ANOVA, $p<0.0001$; unpaired $t$ test between indicated test conditions, ${ }^{* *} p<0.01,{ }^{* * *} p<0.001$, representative of 3 cultures). $\boldsymbol{D}, \boldsymbol{E}$, NFAT luciferase activity is diminished by siRNA treatment against STIM1 and Orai1 (P1; one-way ANOVA, $p<0.0001$; unpaired $t$ test, ${ }^{* *} p<0.01$, representative of 3 cultures; $\left.\boldsymbol{D}\right)$ and in NPCs derived from Orai ${ }^{\mathrm{R} 93 \mathrm{~W} / \mathrm{R} 93 \mathrm{~W}}$ mice $\left(\mathrm{E} 18\right.$; one-way ANOVA, $p<0.0001$; unpaired $t$ test, ${ }^{* *} p<$ $0.01 ; \boldsymbol{E})$. F, Muscarine stimulates nuclear translocation of GFP-NFAT1, which is abolished by BTP-2 (1 $\mu \mathrm{m} ; \mathrm{E} 13, p<0.01$, unpaired $t$ test, $n=219-461$ cells from 4 experiments). $\mathbf{G}$, Theoretical $\left[\mathrm{Ca}^{2+}\right]$ i profiles as a function of distance from an open CRAC channel. The $\left[\mathrm{Ca}^{2+}\right]$ profiles were calculated as described previously (Neher, 1986; Stern, 1992). The single-channel CRAC current was assumed to be $5 \mathrm{fA} . \boldsymbol{H},\left[\mathrm{Ca}^{2+}\right]$ i elevations produced by SOCE in EGTA- or BAPTA-treated cells. NPCs were loaded with $20 \mu \mathrm{m}$ EGTA-AM or $20 \mu \mathrm{m} \mathrm{BAPTA-AM}$ for $25-35$ min at $37^{\circ} \mathrm{C}$. (E13, ${ }^{* * *} p<0.001$, unpaired $t$ test, $n=58-73$ cells; from 2 experiments). $I$, Nuclear translocation is not significantly affected by intracellular EGTA, but is suppressed by BAPTA (E13 and E14; one-way ANOVA, $p=$ 0.0002 ; unpaired $t$ test, $p=0.73$ for EGTA, and ${ }^{* * *} p<0.001$ for BAPTA-treated cells, $n=200-233$ cells from 3 experiments).

diminished in the absence of external $\mathrm{Ca}^{2+}$ or by the CRAC channel inhibitor BTP-2 (Fig. $6 A, B$ ), indicating that $\mathrm{Ca}^{2+}$ influx through CRAC channels is necessary for NFAT translocation. In a second method, we studied the activation of the endogenous NFAT in NPCs using an NFAT-luciferase reporter assay. Activation of SOCE caused robust stimulation of NFAT-mediated gene expression, which was abolished by the CRAC channel inhibitors 2-APB, SKF96365, and BTP-2 and was absent in nominally $\mathrm{Ca}^{2+}$-free medium (Fig. 6C). Moreover, siRNA knock down of
Orail and STIM1 significantly reduced NFAT activity in NPCs (Fig. 6D), and NFAT activation was completely lost in NPCs derived from Orai1 ${ }^{\mathrm{R} 93 \mathrm{~W} / \mathrm{R} 93 \mathrm{~W}}$ knock-in mice (Fig. $6 E$ ). Finally, as expected from the dependence of NFAT activation on calcineurin, the calcineurin antagonist cyclosporine $\mathrm{A}$ abrogated stimulation of NFAT-dependent gene transcription (Fig. 6C). Therefore, these results indicate that $\mathrm{Ca}^{2+}$ influx through CRAC channels activates NFAT-dependent gene expression in NPCs. In addition to direct depletion of $\mathrm{ER} \mathrm{Ca}^{2+}$ stores by thapsigargin, 
$\left[\mathrm{Ca}^{2+}\right]$ i elevations resulting from stimulation of $\mathrm{mAChRs}$ were also effective in stimulating nuclear translocation of GFP-NFAT1 (Fig. $6 F$ ). The muscarine-induced nuclear translocation of GFPNFAT1 was largely prevented by the CRAC channel inhibitor BTP-2 (Fig. 6F), indicating that CRAC channels serve as a key effector mechanism to activate the calcineurin-NFAT pathway after stimulation of metabotropic receptors.

Previous studies have indicated that, in cells expressing multiple subtypes of $\mathrm{Ca}^{2+}$ channels, specificity of gene expression is controlled at least in part by local $\mathrm{Ca}^{2+}$ signals that are sensed by $\mathrm{Ca}^{2+}$-binding proteins located in close proximity to the preferred $\mathrm{Ca}^{2+}$ channel (Deisseroth et al., 1998; Dolmetsch et al., 2001; Di Capite et al., 2009). In this paradigm, $\mathrm{Ca}^{2+}$ acts locally near the plasma membrane to activate a second signal, which in turn leads to stimulation of gene expression in the nucleus. The ability of CRAC channels to signal to the nucleus through calcineurin-NFAT in NPCs therefore led us next to consider whether calcineurin-NFAT signaling may be coupled through a local $\mathrm{Ca}^{2+}$ signal emanating from the CRAC channel. To test this, we studied the differential effects of the slow and fast $\mathrm{Ca}^{2+}$ chelators EGTA and BAPTA, respectively. EGTA and BAPTA have comparable affinities for $\mathrm{Ca}^{2+}(\sim 250 \mathrm{nM}$; Neher, 1986; Stern, 1992). However, the 150 -fold slower $\mathrm{Ca}^{2+}$ binding on-rate of EGTA is expected to produce a region of relatively unbuffered $\left[\mathrm{Ca}^{2+}\right]_{\mathrm{i}}$ around individual $\mathrm{Ca}^{2+}$ channels (Neher, 1986; Stern, 1992). In contrast, the faster $\mathrm{Ca}^{2+}$ binding on-rate of BAPTA would cause $\left[\mathrm{Ca}^{2+}\right]_{\mathrm{i}}$ to drop very steeply to resting levels a few tens of nanometers away from a $\mathrm{Ca}^{2+}$ channel (Fig. $6 G$ ). Therefore, whereas BAPTA is expected to suppress both local and global $\left[\mathrm{Ca}^{2+}\right]_{\mathrm{i}}$ elevations, EGTA should selectively suppress the global $\mathrm{Ca}^{2+}$ signal (Neher, 1986; Stern, 1992). The differential effects of EGTA and BAPTA have been widely used to map the local coupling of $\mathrm{Ca}^{2+}$ channels to $\mathrm{Ca}^{2+}$-activated $\mathrm{K}^{+}$channels (Roberts et al., 1990; Prakriya et al., 1996; Prakriya and Lingle, 2000), the neurotranmitter release machinery (Adler et al., 1991; Rozov et al., 2001), and gene transcriptional machinery (Deisseroth et al., 1996; Kar et al., 2011).

Figure $6, H$ and $I$, shows the effects of EGTA and BAPTA on the bulk $\mathrm{Ca}^{2+}$ signal as measured using fura- $2 \mathrm{Ca}^{2+}$ imaging and on translocation of GFP-NFAT1. Both EGTA and BAPTA strongly suppressed the global $\left[\mathrm{Ca}^{2+}\right]_{\mathrm{i}}$ signal resulting from SOCE (Fig. 6H). However, whereas BAPTA nearly completely eliminated the nuclear translocation of GFP-NFAT1, EGTA had no effect (Fig. 6I). The failure of EGTA to suppress GFP-NFAT nuclear translocation while strongly attenuating the global rise in $\left[\mathrm{Ca}^{2+}\right]_{\mathrm{i}}$ indicates that the global rise in $\left[\mathrm{Ca}^{2+}\right]_{\mathrm{i}}$ after CRAC channel activation is poorly correlated with NFAT activation. Therefore, these results are consistent with the hypothesis that NFAT is activated by a local $\mathrm{Ca}^{2+}$ signal closely coupled to CRAC channels. Because NFAT is activated by calmodulin (CaM)calcineurin-dependent dephosphorylation, these results suggest that calcineurin-NFAT signaling is turned on by a local $\mathrm{Ca}^{2+}$ signal, likely through local activation of CaM-calcineurin by CRAC channels. We will consider potential mechanisms that mediate this coupling in the Discussion.

\section{Suppressing CRAC channels diminishes NPC proliferation}

Previous studies have shown that $\mathrm{Ca}^{2+}$ elevations induced by mitogens and neurotransmitters have a powerful influence on the proliferation of NPCs (Ma et al., 2000; Maric et al., 2003; Fiorio Pla et al., 2005). The finding that EGF and muscarine activate CRAC channels in NPCs (Fig. 5) therefore led us to consider whether CRAC channels contribute to NPC proliferation. To examine this possibility, we first tested the effects of STIM1 and Orail knock down on actively proliferating NPCs labeled with EdU, a thymidine analog that is incorporated into the DNA of dividing cells in the S-phase of the cell cycle. These experiments revealed that siRNA-mediated knock down of STIM1 or Orail results in significant reduction in the fraction of $\mathrm{EdU}^{+}$cells in both embryonic (Fig. $7 A, B$ ) and adult NPCs (Fig. 7D,E). Moreover, MTT assays to monitor total cell densities showed a significant decrease in the proliferation of siOrail-treated cells (Fig. 7C). Interestingly, proliferation of NPCs was also diminished by cyclosporine A (Fig. 7F, G), an antagonist of calcineurin that inhibits NFAT activation and is a drug widely used for immune suppression (Crabtree and Olson, 2002; Hogan et al., 2003). Therefore, these results indicate that STIM1 and Orail regulate NPC proliferation through a mechanism that likely involves calcineurin-NFAT signaling.

To examine the contributions of CRAC channels for NPC proliferation in the Orail ${ }^{\mathrm{R} 93 \mathrm{~W} / \mathrm{R} 93 \mathrm{~W}}$ knock-in mice, we performed two types of analyses. In one method, we examined the proliferation of NPCs from embryonic mice grown in FGF alone, which reflects the basal proliferation of these cells. EdU labeling of NPCs derived from embryonic Orai1 ${ }^{\text {R93W/R93W }}$ mice grown in FGF alone did not reveal a difference in basal proliferation (Fig. $8 B$ ). Nonetheless, examination of cell growth curves using MTT assays revealed a small but significant decrease in average cell densities in Orai1 ${ }^{\text {R93W/R93W }}$ NPCs grown in FGF compared with WT cells (Fig. 8C). In a second method, we studied the enhanced proliferation of NPCs stimulated by the mitogen EGF. Stimulation of NPCs (E14 embryos) with EGF resulted in strong enhancement of NPC proliferation as assessed by EdU incorporation and MTT cell growth assays (Fig. 8A-C). The enhancement of EdU incorporation stimulated by EGF was diminished both in the heterozygous Orail ${ }^{\mathrm{R} 93 \mathrm{~W} /+}$ and in homozygous Orail ${ }^{\text {R93W/R93W }}$ mice (Fig. $8 B$ ). Likewise, MTT cell growth assays revealed a significant loss of proliferation in Orai1 ${ }^{\mathrm{R} 93 \mathrm{~W} / \mathrm{R} 93 \mathrm{~W}}$ mice (Fig. $8 C$ ). Therefore, loss of Orail function attenuates proliferation of NPCs, demonstrating a role for SOCE in regulating both basal and EGF-stimulated NPC proliferation. The decrease in the fraction of actively dividing NPCs in CRAC-channel-deficient cells is not an indirect consequence of increased apoptosis, because estimates of the fraction of apoptotic cells were comparable in WT and CRAC-channel-deficient NPCs (Fig. 8D). Together, these results indicate that $\mathrm{Ca}^{2+}$ signaling through CRAC channels regulates NPC proliferation.

One possible explanation for the differing effects of Orail deficiency in NPCs cultured in the presence of FGF alone between the two EdU tests and MTT assays in the Orai1R93Wtransgenic mice (Fig. $8 \mathrm{~B}, \mathrm{C}$ ) may lie in the differing methodologies of the assays: because EdU tests only provide a snapshot of EdU incorporation in the S-phase, a population of NPCs that asymmetrically divide into quiescent cells will also incorporate EdU to the same extent as progenitors that retain proliferative capacity and continue to divide. In contrast, MTT assays reveal cell densities over a period of days and thus better reflect overall differences in rates of proliferation taking into account possible variations in progenitor populations. The high concentrations of growth factors $(10-20 \mathrm{ng} / \mathrm{ml})$ in which these cells are grown may also partially overcome deficits in basal proliferation, as assessed by EdU incorporation, due to chronic CRAC channel deficiency. Nonetheless, the decrease in cell growth revealed by the MTT assays indicates that Orail loss-of-function or deficiency modulates NPC proliferation. 
A E13 NPCs

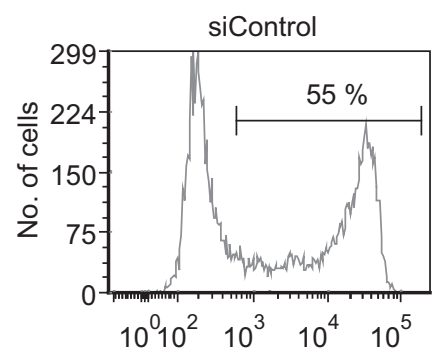

EdU-Alexa 488 intensity

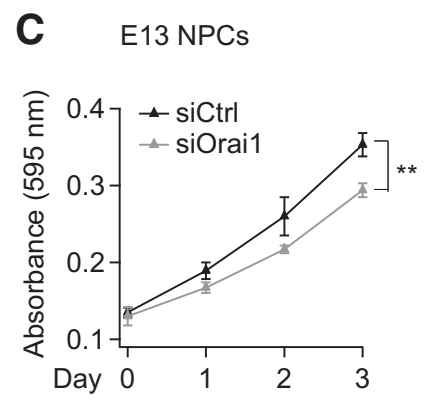

F $\quad$ E13 NPCs

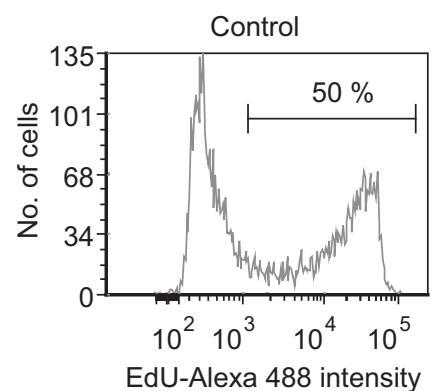

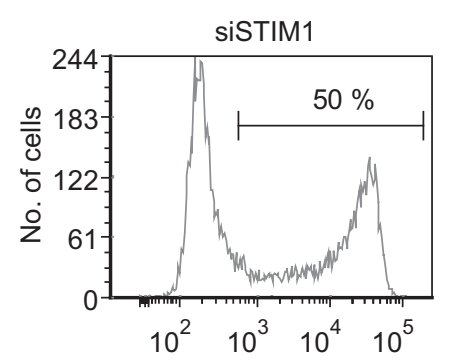

EdU-Alexa 488 intensity

\section{Adult NPCs}

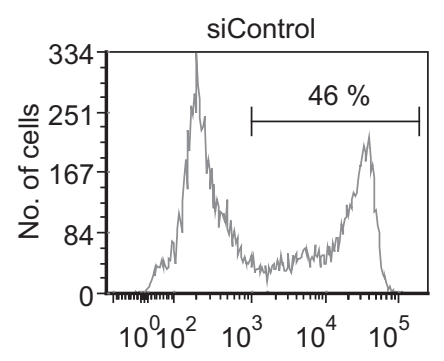

EdU-Alexa 488 intensity

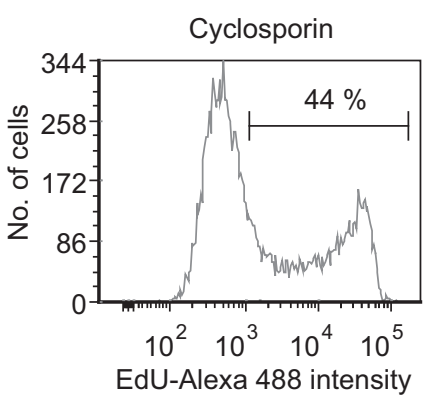

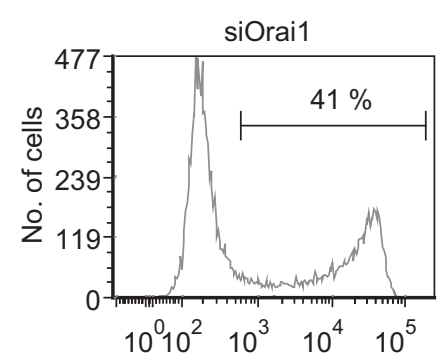

EdU-Alexa 488 intensity

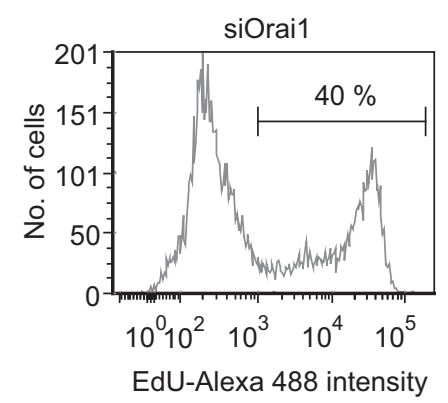

G E13 and E14 NPCs

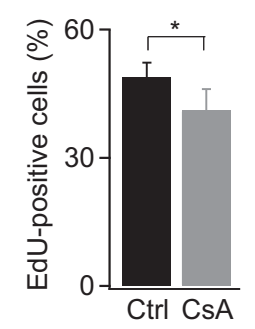

B E13 and E14 NPCs

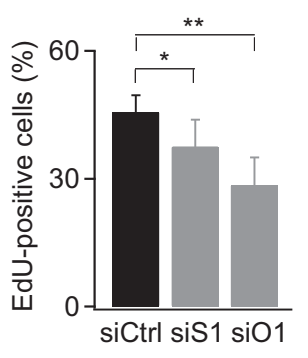

E Adult NPCs

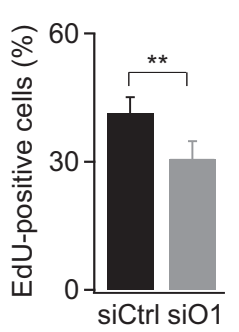

Figure 7. Suppression of STIM1 or Orai1 expression diminishes NPC proliferation. $A, N P C s$ were nucleofected with the indicated siRNA constructs and incorporation of EdU was analyzed by flow cytometry. $\boldsymbol{B}$, Summary of EdU incorporation for the indicated conditions (E13 and E14 mice; $p$-values determined by ANOVA followed by post hoc paired $t$ tests, ${ }^{*} p=0.05,{ }^{* *} p<0.01, n=6$ experiments). C, Knockdown of Orai1 expression diminishes NPC cell density. Cell density was assessed by an MTT colorimetric assay. The $x$-axis shows duration in days after nucleofection and seeding of NPCs at day 0 (E13, $p=0.01$ at day 5, 2-sample unpaired $t$ test, representative of 3 experiments). D, NPCs derived from adult mice show diminished EdU incorporation after Orai 1 knock down. $\boldsymbol{E}$, Summary of the effects of siRNA knock down of Orai1 (adult mice, $7-10 \mathrm{wk}, p=0.008,2$-sample paired $t$ test, $n=4$ experiments from 3 cultures). $\boldsymbol{F}, \boldsymbol{G}$, The calcineurin inhibitor cyclosporin $\mathrm{A}$ $(5 \mu \mathrm{M})$ diminishes NPC proliferation. NPCs were treated with CsA once every $24 \mathrm{~h}$ for $48 \mathrm{~h}$ before EdU incorporation (E13 and E14, ${ }^{*} p<0.05$, paired $t$ test, $n=3$ experiments).

Although growing NPCs in culture as neurospheres is a popular and useful method for studying stem and progenitor cell behaviors in vitro, the properties of NPCs grown in cell culture are not likely to be identical to those expressed in vivo in their native milieu (Reynolds and Rietze, 2005; Pastrana et al., 2011). We therefore also investigated whether deleting CRAC channel expression affects the proliferation of NSCs in the subventricular zone in vivo in adult mice. For these studies, actively dividing cells were labeled by injecting mice intraperitoneally with a single injection of the thymidine analog BrdU. Mice were killed $24 \mathrm{~h}$ after injection and BrdU incorporation into the rapidly dividing cells was examined in fixed brain sections by counting the total number of $\mathrm{BrdU}^{+}$cells in matched Orai ${ }^{\mathrm{f} / \mathrm{fl}: \mathrm{Nes}-\mathrm{Cre}}$ and Orai $1^{\mathrm{f} / \mathrm{fl}}$ coronal sections. This analysis of adult mice revealed a marked decrease in the number of proliferating cells in the subventricular zone in Orai ${ }^{\mathrm{f} / \mathrm{fll} \text { :Nes-Cre }}$ mice (Fig. 9E). BrdU ${ }^{+}$cells were distributed, as expected, along the lateral ventricle wall in both cases, indicating that the Orail KO brains have a generalized decrease in the number of proliferating cells in the SVZ and that this is not due to selective loss of proliferation in a particular subregion within the SVZ. TUNEL staining did not reveal significant levels of apoptosis in either Orai $1^{\mathrm{f} / \mathrm{fl}}$ nor Orai1 ${ }^{\mathrm{f} / \mathrm{fl} \text { :Nes-Cre }}$ brains (Fig. $9 D$ ), indicating that, as in cultured NPCs (Fig. $8 D$ ), the diminished BrdU labeling is not due to enhanced apoptosis.

The attenuation of NPC proliferation in vivo could arise because lack of CRAC channel function diminishes proliferation of adult progenitors directly. However, it could also be a consequence of a developmental deficit in which adult mice lacking Orail contain reduced numbers of progenitors at the outset due to depletion of progenitors during embryonic development. Unfortunately, our attempts to examine this issue directly using an inducible KO system of tamoxifen injections in adult STIM1 Cre$\mathrm{ER}^{\mathrm{T} 2}$ mice were complicated by increases in $\left[\mathrm{Ca}^{2+}\right] \mathrm{i}$ caused by tamoxifen itself (data not shown) (Zhang et al., 2000; Chang et al., 2002). To overcome this problem and to gain insight into the role of CRAC channels for regulating the intrinsic proliferative potential of adult NPCs, we examined NPCs cultured as neurospheres from adult Orai ${ }^{\mathrm{f} / \mathrm{fl}: \mathrm{Nes}-\mathrm{Cre}}$ mice. This analysis revealed 
A

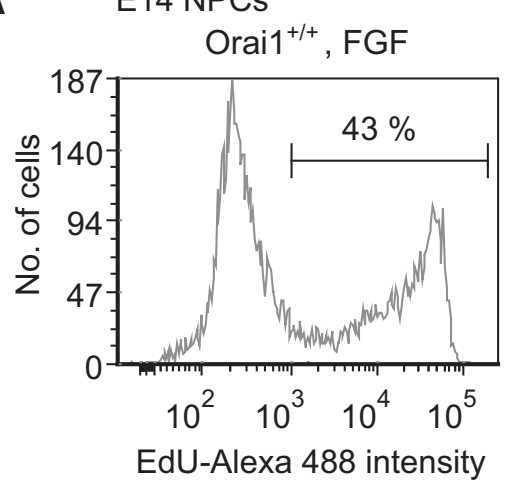

B

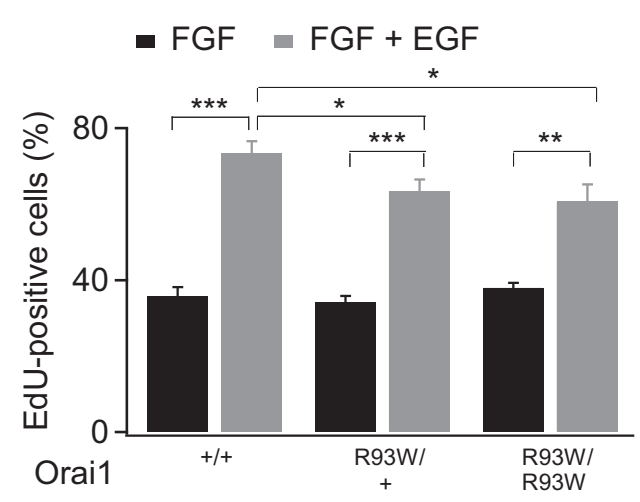

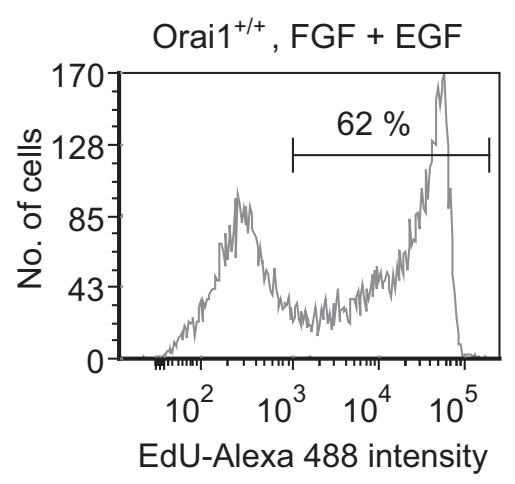

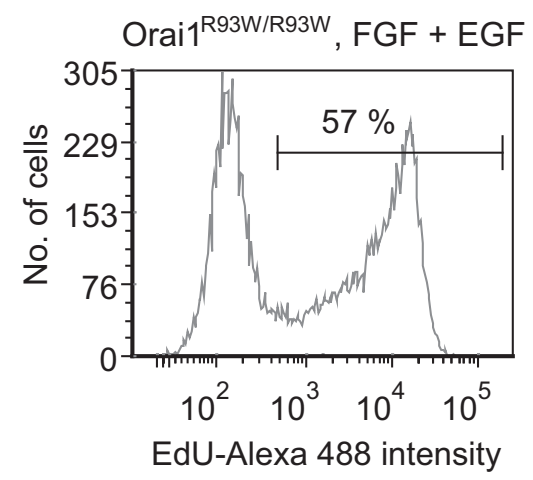

C E13 NPCs

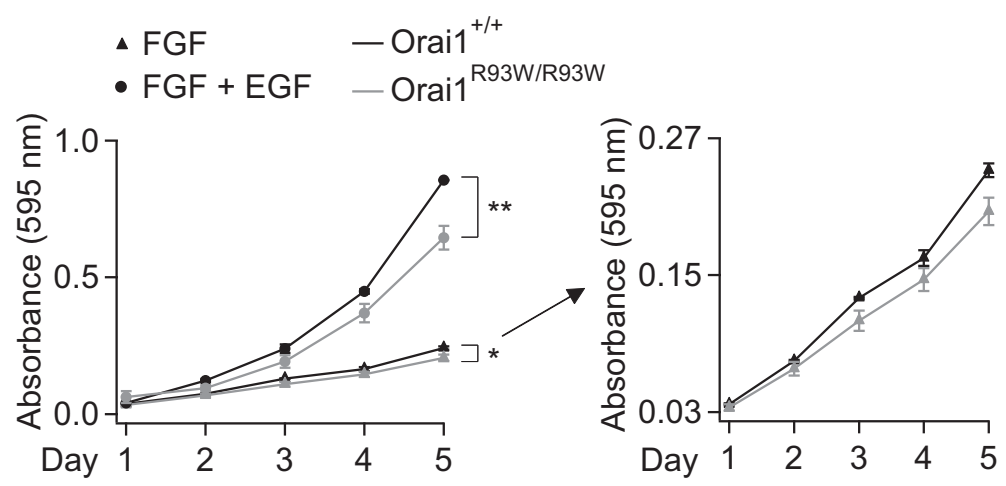

\section{D $\quad$ E14 NPCs}

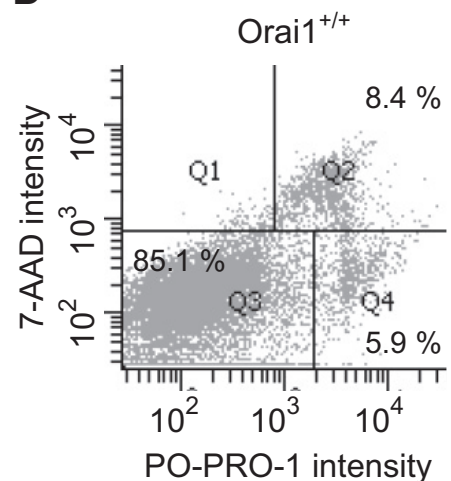

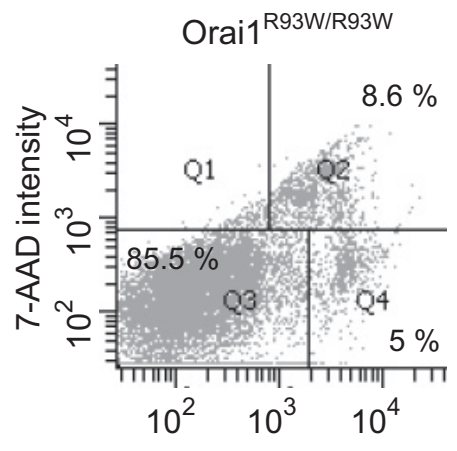

PO-PRO-1 intensity

Figure 8. Proliferation is diminished in NPCs from transgenic mice lacking functional Orai1 channels. $A$, EdU analysis of embryonic NPCs from Orai ${ }^{+/+}$and 0 rai $1^{\text {R93W/R93W }}$ mice grown in $\mathrm{FGF}$ $(10 \mathrm{ng} / \mathrm{ml})$ or FGF and EGF (10 $\mathrm{ng} / \mathrm{ml}$ each). NPCs were grown for $24-48 \mathrm{~h}$ before EdU labeling $(3-8 \mathrm{~h})$. B, Summary of the fraction of EdU-labeled cells under different growth conditions. EGF-stimulated proliferation of NPCs is attenuated in Orai $1{ }^{\mathrm{R} 93 \mathrm{~W} / \mathrm{R} 93 \mathrm{~W}} \mathrm{NPCs}$ (E13-E14, 2-way ANOVA followed by post hoc $t$ test, $n=8-19$ experiments/mice for each genotype, 5 cultures; ${ }^{*} p<$ $\left.0.05,{ }^{* *} p<0.01,{ }^{* * *} p<0.001\right)$. C, MTT cell growth assays show decreased NPC cell densities in Orai $1{ }^{\text {R93W/R93W }}$ mice. Right, Same experiment on a magnified $y$-axis scale to better visualize the difference between Orai ${ }^{\mathrm{R} 93 \mathrm{~W} / \mathrm{R} 93 \mathrm{~W}}$ and WT cells grown in FGF alone ( $\mathrm{E} 13,{ }^{*} p<0.05,{ }^{* *} p<0.01$ unpaired $t$ test, $n=3$ experiments, representative of 3 cultures). D, Apoptosis is not significantly

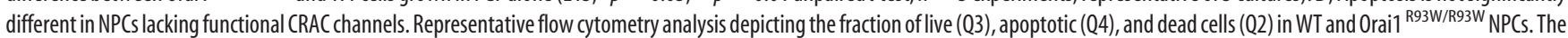
percentage of apoptotic cells is indicated in the bottom right box. E14 embryos were used for this experiment.

strong suppression of proliferation in NPCs derived from adult Orai1 ${ }^{\mathrm{fl} / \mathrm{fl}: \mathrm{Nes}-\mathrm{Cre}}$ mice. Likewise, NPCs grown from heterozygous Orail ${ }^{\mathrm{R} 93 \mathrm{~W} /+}$ mice (which survive into adulthood, unlike the homozygous Orai1 ${ }^{\text {R93W/R93W }}$ mice) also showed significant deficits in proliferation. Therefore, these results demonstrate that ablation or loss-of-function of Orail channels results in an intrinsic defect in NPC proliferation in adult NPCs, suggesting that the reduced BrdU labeling seen in the adult Orai $1^{\mathrm{fl} / \mathrm{fl} \text { Nes-Cre }}$ mice is unlikely to be solely due to a developmental deficit. Together with the in vitro results described for the embryonic cells (Fig. 8), these results indicate that CRAC channels play a significant role in regulating both embryonic and adult NPC proliferation.

\section{Discussion}

$\mathrm{Ca}^{2+}$ signaling is crucial for many aspects of neurogenesis, including proliferation, migration, and differentiation (Komuro and Rakic, 1996; Spitzer et al., 2004; Weissman et al., 2004; Hanson et al., 2008). $\mathrm{Ca}^{2+}$ signals are shaped by interactions among ion channels, pumps, and buffers and regulation of these molecules offers abundant opportunities for signal modulation and manipulation of downstream responses (Clapham, 2007). Growing evidence indicates that aberrant $\mathrm{Ca}^{2+}$ signals are detrimental for the proper "choreography" of events in neural development (Spitzer et al., 2005), which has sparked considerable interest 
A

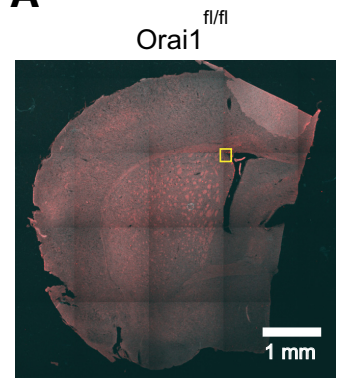

$\mathrm{DAPI}+\mathrm{BrdU}$

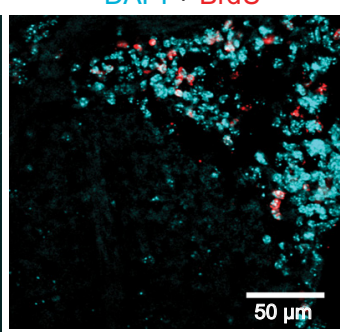

B

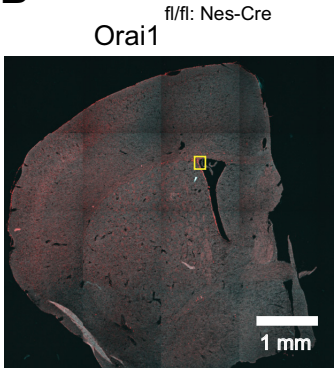

C

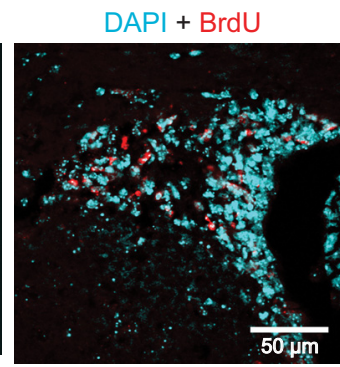

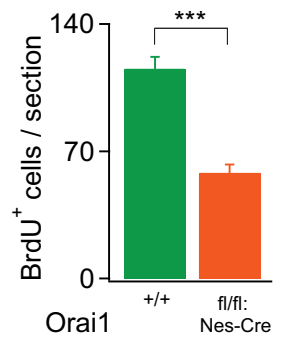

D
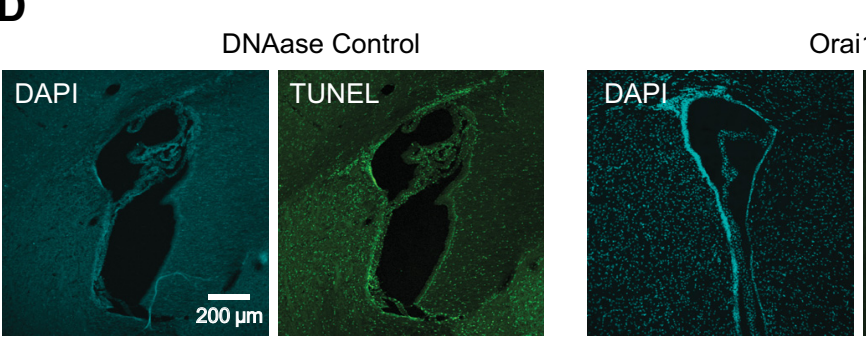

Orai1 $^{\mathrm{fl} / \mathrm{fl}}$
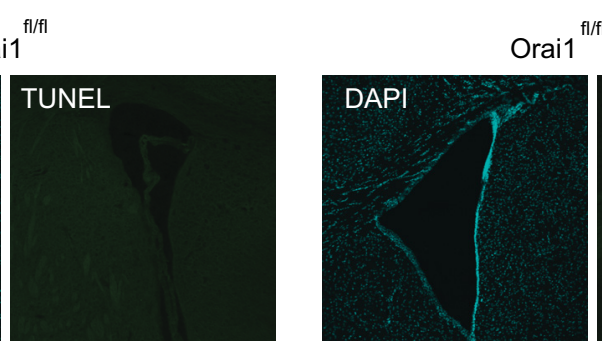

fl/fl: Nes-Cre

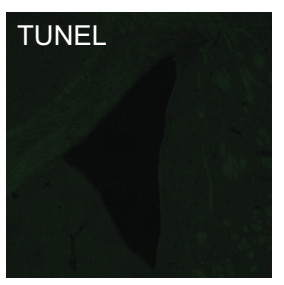

E

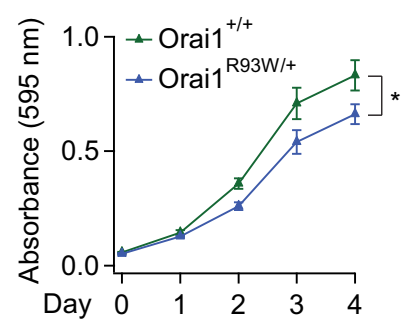

F $\quad$ Adult NPCs

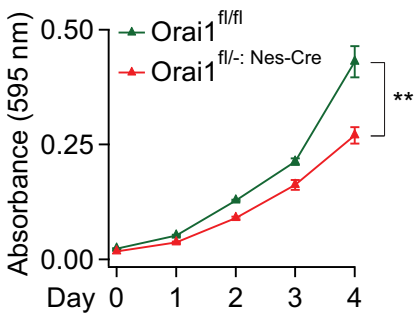

Figure 9. Adult mice lacking Orai1 exhibit diminished NSC proliferation in vivo and in vitro. $\boldsymbol{A}, \boldsymbol{B}$, Whole-mount images of coronal brain sections containing the SVZ from Orai1 ${ }^{\mathrm{fl} / \mathrm{fl}}(\boldsymbol{A})$ or Orai $^{\text {flff:Nes-Cre }}$ mice $(\boldsymbol{B}$; low-magnification images are on shown on the left). Example confocal images at a high magnification $(60 \times)$ of BrdU immunostaining (red) and DAPI (cyan) in the dorsolateral SVZ are shown on the right. Images were collected in the dorsolateral SVZ. C, Summary of the average number of BrdU-labeled cells per section in WT and KO mice (adult mice, 6 weeks old, ${ }^{* * *} p<0.001$, unpaired $t$ test; $12-13$ sections analyzed from 3 mice for each condition). D. TUNEL staining does not show significant levels of ongoing apoptosis or necrosis in Orai $1 / \mathrm{f} / \mathrm{fl}$ or Orai $^{\text {f/ff:Nes-Cre }}$ mice. $E, F$, MTT colorimetric cell growth assays in NPCs obtained from adult Orai $1^{\text {R93W/+ }}$ NPCs (9 weeks old) or Oraii ${ }^{\text {flft:Nes-Cre }}$ mice $\left(11\right.$ weeks old; ${ }^{*} p<0.05,{ }^{* *} p<0.01$, unpaired $t$ test, $n=3$ experiments). Cells were seeded at day 0 .

over the years to understand the molecules and mechanisms of $\mathrm{Ca}^{2+}$ signaling in neurons and glia. However, the functional architecture of the $\mathrm{Ca}^{2+}$-signaling networks in NPCs-the molecular entities and their organization and how this machinery regulates the physiology of these cells-is not well understood. Previous studies indicate that voltage-gated $\mathrm{Ca}^{2+}$ channels emerge gradually at later stages in the evolution of NPCs (Maric et al., 2000; Cai et al., 2004; Fiorio Pla et al., 2005; Moe et al., 2005; D’Ascenzo et al., 2006; Yasuda et al., 2008), leading to the possibility that early stage NPCs must use alternate $\mathrm{Ca}^{2+}$ influx mechanisms to generate $\mathrm{Ca}^{2+}$ signals. In this study, we find that subventricular zone NPCs exhibit SOCE mediated by the CRAC channel proteins STIM1 and Orail. The ensuing $\mathrm{Ca}^{2+}$ signal regulates $\mathrm{Ca}^{2+}$-dependent gene expression through the calcineurin/NFAT pathway and proliferation of NPCs. In addition to revealing a novel mechanism for the regulation of embryonic and adult neurogenesis, these results identify CRAC channels as a new target that could be relevant for current efforts to develop new therapies using NSCs/NPCs.

\section{Mouse NPCs exhibit SOCE mediated by CRAC channels}

We demonstrate that SVZ NPCs exhibit SOCE that is encoded by the canonical CRAC channel proteins STIM1 and Orail (Figs. 1, $2,3)$. These results confirm and extend previous reports showing that neuroepithelial, neuroblastoma, and glioblastoma cells express SOCE and its machinery (Sakaki et al., 1997; Brown et al., 2005; Liu et al., 2011; Li et al., 2012; Motiani et al., 2013). However, our data do not rule out a role for the other CRAC channel molecules STIM2, Orai2, and Orai3. In fact, brain-specific deletion of Orail in adult mice does not completely abolish SOCE (Fig. $3 C$ ), and the residual $\mathrm{Ca}^{2+}$ entry is inhibited by low concentrations of $\mathrm{La}^{3+}(2 \mu \mathrm{M})$, consistent with the possibility that other Orai paralogs (Orai2/3) may also be expressed and contribute to $\mathrm{Ca}^{2+}$ signaling in adult NPCs. It is worth noting that the conspicuous role for Orail found in our studies differs from most previous published studies and mapping efforts of the Allen Institute (http://mouse.brain-map.org/), which implicate Orai2 and Orai3 as the key Orai paralogs expressed in brain (Gross et al., 2007; Gwack et al., 2007; Wissenbach et al., 2007; Berna-Erro et al., 2009). The published evidence, however, is based largely on 
Western blot or mRNA analysis of whole-brain lysates and could mask heterogeneity between different cell types. These differing results highlight the need for more in-depth analysis of the expression of Orai and STIM proteins in the nervous system using specific reagents such as antibodies and $\mathrm{KO}$ mice.

The majority of the NPCs we tested in culture for SOCE also expressed the progenitor marker nestin and a high fraction of the adult NPCs also expressed the classical astrocyte marker GFAP (Fig. 4). This result is consistent with long-standing observations that $\mathrm{GFAP}^{+}$neurogenic progenitors are present in the SVZ and the subgranular zone of the dentate gyrus in the adult brains (Altman and Das, 1965; Altman, 1969; Doetsch et al., 1999). These GFAP ${ }^{+}$cells remain in the cell cycle and are the predominant source of constitutive adult neurogenesis (Garcia et al., 2004). Therefore, the presence of SOCE appears to be well correlated with classical markers for progenitors with neurogenic potential. In contrast, SOCE was significantly attenuated in progenitors expressing the DCX-GFP transgene, and immunostaining revealed low frequency of coexpression of DCX and Orail (Fig. 4). Therefore, these results suggest that maturation of progenitors towards a neuronal potential is associated with downregulation of SOCE. This finding, however, does not necessarily imply that mature neurons do not express SOCE. On the contrary, there is considerable evidence for the presence of both SOCE and the expression of STIM and Orai proteins in many mature neurons (Berna-Erro et al., 2009; Gemes et al., 2011), suggesting that at least subpopulations of mature neurons regain the machinery for SOCE following developmental maturation.

\section{CRAC channels activate NFAT-dependent gene expression in NPCs}

NFAT is widely expressed in the nervous system (Graef et al., 2003; Kao et al., 2009), yet its functional roles in the brain are only now beginning to be understood. NFAT-directed gene transcription regulates the expression of $\mathrm{IP}_{3} \mathrm{Rs}$, GluRs, and pronociceptive genes in neurons (Groth and Mermelstein, 2003; Groth et al., 2007; Groth et al., 2008). Moreover, calcineurin-NFAT signaling is critical for neurotrophin-mediated axonal outgrowth (Nguyen and Di Giovanni, 2008) and Schwann-cell-mediated myelination of peripheral nerve fibers (Kao et al., 2009). However, the sources of $\mathrm{Ca}^{2+}$ entry that activate NFAT are largely unknown in the brain. Here, we demonstrate that CRAC channels stimulate nuclear translocation of NFAT and NFAT-dependent gene transcription in NPCs. Therefore, CRAC channel activation of calcineurin-NFAT signaling may be a key mechanism that underlies the effector response by $\mathrm{Ca}^{2+}$ signals in the nervous system. Interestingly, we find that NFAT activation is preferentially stimulated by local $\mathrm{Ca}^{2+}$ signals after CRAC channel activation (Fig. $6 \mathrm{H}, \mathrm{I})$. This finding is reminiscent of reports showing a tight spatial association between store-operated channels and NFAT activation in HEK293 cells (Kar et al., 2011) and between voltageactivated L-type $\mathrm{Ca}^{2+}$ channels and NFAT in hippocampal neurons (Oliveria et al., 2007). In hippocampal neurons, calcineurin is directly tethered to L-type $\mathrm{Ca}^{2+}$ channels via the anchoring protein AKAP79/150 (Oliveria et al., 2007). Therefore, it is possible that a similar molecular mechanism involving tethers between the calcineurin/NFAT machinery and Orail channels may underlie local activation of NFAT by CRAC channels in NPCs.

\section{CRAC channels regulate NPC proliferation}

Many growth factors and neurotransmitters that regulate neurogenesis are mechanistically linked to $\mathrm{Ca}^{2+}$ signaling. For example, EGF, a well known regulator of NPC proliferation and differentiation, mobilizes $\mathrm{Ca}^{2+}$ signaling via activation of a receptor tyrosine kinase coupled to the PLC $\gamma$-IP 3 pathway (Ullrich and Schlessinger, 1990; Maric et al., 2003). Likewise, cholinergic signaling, which triggers $\mathrm{Ca}^{2+}$ mobilization, has long been reported to regulate neurogenesis and proliferation (Ma et al., 2000; Li et al., 2001; Calza et al., 2003; Resende and Adhikari, 2009). However, the cellular machinery that mediates $\mathrm{Ca}^{2+}$ entry in response to these and other factors has remained unclear. Our findings indicate that CRAC channels are a major mechanism for the sustained and oscillatory $\mathrm{Ca}^{2+}$ signals activated by EGF and ACh (Fig. 5) and raise the possibility that CRAC channels serve as a key mechanism in the regulation of neurogenesis by mitogens, growth factors, and neurotransmitters.

Consistent with this possibility, we find that deletion of CRAC channel expression or loss of CRAC channel function significantly diminishes both constitutive and EGF-stimulated NPC proliferation (Figs. 7, 8, 9). The suppression of NPC proliferation is observed, not only in vitro in NPCs cultured as neurospheres (Figs. 7,8 ), but also in vivo in tissue slices from Orail-deficient mice (Fig. 9). Moreover, attenuation of NPC proliferations is not an indirect consequence of enhanced apoptosis. These novel findings indicate that CRAC channels regulate the self-renewal of NSCs/NPCs.

How do CRAC channels regulate NPC proliferation? It is known that $\mathrm{Ca}^{2+}$ signals accelerate the progression of cells through the cell cycle, specifically by speeding exit from quiescence in the early $G_{1}$ and $G_{1} / S$ transition phases (Berridge, 1995; Munaron et al., 2004). This effect occurs through modulation of the expression and function of several cell cycle proteins, including cyclins (Sée et al., 2004; Karpurapu et al., 2008; Karpurapu et al., 2010; Singh et al., 2010). Previous studies have shown that the expression of cyclins is transcriptionally regulated by NFAT (Karpurapu et al., 2008; Karpurapu et al., 2010; Singh et al., 2010). Therefore, it is tempting to speculate that CRAC channels regulate NPC proliferation through control of calcineurin/NFAT signaling. Consistent with this possibility, cyclosporine A diminishes NPC proliferation (Fig. 7G). Therefore, these findings are compatible with the scenario that CRAC channels regulate neurogenesis, at least in part through transcriptional control of the expression of cell cycle proteins.

In summary, we describe a novel signaling pathway that regulates NPC proliferation and neurogenesis. Because the ventricular zones in the mammalian brain are niches for neural precursors that continue to proliferate into adulthood (Merkle and Alvarez-Buylla, 2006), the regulation of NPC proliferation by CRAC channels may have implications not only for brain development, but also for harnessing the full therapeutic potential of NPCs after brain injury and the treatment of neurodegenerative diseases.

\section{References}

Adler EM, Augustine GJ, Duffy SN, Charlton MP (1991) Alien intracellular calcium chelators attenuate neurotransmitter release at the squid giant synapse. J Neurosci 11:1496-1507. Medline

Altman J (1969) Autoradiographic and histological studies of postnatal neurogenesis. IV. Cell proliferation and migration in the anterior forebrain, with special reference to persisting neurogenesis in the olfactory bulb. J Comp Neurol 137:433-457. CrossRef Medline

Altman J, Das GD (1965) Autoradiographic and histological evidence of postnatal hippocampal neurogenesis in rats. J Comp Neurol 124:319335. CrossRef Medline

Baba A, Yasui T, Fujisawa S, Yamada RX, Yamada MK, Nishiyama N, Matsuki N, Ikegaya Y (2003) Activity-evoked capacitative $\mathrm{Ca}^{2+}$ entry: implications in synaptic plasticity. J Neurosci 23:7737-7741. Medline

Bates B, Rios M, Trumpp A, Chen C, Fan G, Bishop JM, Jaenisch R (1999) 
Neurotrophin-3 is required for proper cerebellar development. Nat Neurosci 2:115-117. CrossRef Medline

Belmadani A, Tran PB, Ren D, Assimacopoulos S, Grove EA, Miller RJ (2005) The chemokine stromal cell-derived factor-1 regulates the migration of sensory neuron progenitors. J Neurosci 25:3995-4003. CrossRef Medline

Bergmeier W, Oh-Hora M, McCarl CA, Roden RC, Bray PF, Feske S (2009) R93W mutation in Orail causes impaired calcium influx in platelets. Blood 113:675-678. CrossRef Medline

Berna-Erro A, Braun A, Kraft R, Kleinschnitz C, Schuhmann MK, Stegner D, Wultsch T, Eilers J, Meuth SG, Stoll G, Nieswandt B (2009) STIM2 regulates capacitive $\mathrm{Ca}^{2+}$ entry in neurons and plays a key role in hypoxic neuronal cell death. Sci Signal 2:ra67. CrossRef Medline

Berridge MJ (1995) Calcium signalling and cell proliferation. Bioessays 17: 491-500. CrossRef Medline

Bhattacharyya BJ, Banisadr G, Jung H, Ren D, Cronshaw DG, Zou Y, Miller RJ (2008) The chemokine stromal cell-derived factor-1 regulates GABAergic inputs to neural progenitors in the postnatal dentate gyrus. J Neurosci 28:6720-6730. CrossRef Medline

Bonaguidi MA, McGuire T, Hu M, Kan L, Samanta J, Kessler JA (2005) LIF and BMP signaling generate separate and discrete types of GFAPexpressing cells. Development 132:5503-5514. CrossRef Medline

Brown AM, Riddoch FC, Robson A, Redfern CP, Cheek TR (2005) Mechanistic and functional changes in $\mathrm{Ca}^{2+}$ entry after retinoic acid-induced differentiation of neuroblastoma cells. Biochem J 388:941-948. CrossRef Medline

Cai J, Cheng A, Luo Y, Lu C, Mattson MP, Rao MS, Furukawa K (2004) Membrane properties of rat embryonic multipotent neural stem cells. J Neurochem 88:212-226. CrossRef Medline

Calza L, Giuliani A, Fernandez M, Pirondi S, D’Intino G, Aloe L, Giardino L (2003) Neural stem cells and cholinergic neurons: regulation by immunolesion and treatment with mitogens, retinoic acid, and nerve growth factor. Proc Natl Acad Sci U S A 100:7325-7330. CrossRef Medline

Chang HT, Huang JK, Wang JL, Cheng JS, Lee KC, Lo YK, Liu CP, Chou KJ, Chen WC, Su W, Law YP, Jan CR (2002) Tamoxifen-induced increases in cytoplasmic free $\mathrm{Ca}^{2+}$ levels in human breast cancer cells. Breast Cancer Res Treat 71:125-131. CrossRef Medline

Clapham DE (2007) Calcium signaling. Cell 131:1047-1058. CrossRef Medline

Crabtree GR, Olson EN (2002) NFAT signaling: choreographing the social lives of cells. Cell 109:S67-79. CrossRef Medline

D’Ascenzo M, Piacentini R, Casalbore P, Budoni M, Pallini R, Azzena GB, Grassi C (2006) Role of L-type $\mathrm{Ca}^{2+}$ channels in neural stem/progenitor cell differentiation. Eur J Neurosci 23:935-944. CrossRef Medline

Deisseroth K, Bito H, Tsien RW (1996) Signaling from synapse to nucleus: postsynaptic CREB phosphorylation during multiple forms of hippocampal synaptic plasticity. Neuron 16:89-101. CrossRef Medline

Deisseroth K, Heist EK, Tsien RW (1998) Translocation of calmodulin to the nucleus supports CREB phosphorylation in hippocampal neurons. Nature 392:198-202. CrossRef Medline

Deisseroth K, Singla S, Toda H, Monje M, Palmer TD, Malenka RC (2004) Excitation-neurogenesis coupling in adult neural stem/progenitor cells. Neuron 42:535-552. CrossRef Medline

Di Capite J, Ng SW, Parekh AB (2009) Decoding of cytoplasmic $\mathrm{Ca}^{2+}$ oscillations through the spatial signature drives gene expression. Curr Biol 19:853-858. CrossRef Medline

Doetsch F, Caillé I, Lim DA, García-Verdugo JM, Alvarez-Buylla A (1999) Subventricular zone astrocytes are neural stem cells in the adult mammalian brain. Cell 97:703-716. CrossRef Medline

Dolmetsch RE, Xu K, Lewis RS (1998) Calcium oscillations increase the efficiency and specificity of gene expression. Nature 392:933-936. CrossRef Medline

Dolmetsch RE, Pajvani U, Fife K, Spotts JM, Greenberg ME (2001) Signaling to the nucleus by an L-type calcium channel-calmodulin complex through the MAP kinase pathway. Science 294:333-339. CrossRef Medline

Emptage NJ, Reid CA, Fine A (2001) Calcium stores in hippocampal synaptic boutons mediate sort-term plasticity, store-operated $\mathrm{Ca}\left({ }^{2+}\right)$ entry, and spontaneous transmitter release. Neuron 29:197-208. CrossRef Medline

Felder CC (1995) Muscarinic acetylcholine receptors: signal transduction through multiple effectors. FASEB J 9:619-625. Medline
Feske S, Gwack Y, Prakriya M, Srikanth S, Puppel SH, Tanasa B, Hogan PG, Lewis RS, Daly M, Rao A (2006) A mutation in Orail causes immune deficiency by abrogating CRAC channel function. Nature 441:179-185. CrossRef Medline

Fiorio Pla A, Maric D, Brazer SC, Giacobini P, Liu X, Chang YH, Ambudkar IS, Barker JL (2005) Canonical transient receptor potential 1 plays a role in basic fibroblast growth factor (bFGF)/FGF receptor-1-induced $\mathrm{Ca}^{2+}$ entry and embryonic rat neural stem cell proliferation. J Neurosci 25: 2687-2701. CrossRef Medline

Fukushima M, Tomita T, Janoshazi A, Putney JW (2012) Alternative translation initiation gives rise to two isoforms of Orail with distinct plasma membrane mobilities. J Cell Sci 125:4354-4361. CrossRef Medline

Garcia AD, Doan NB, Imura T, Bush TG, Sofroniew MV (2004) GFAPexpressing progenitors are the principal source of constitutive neurogenesis in adult mouse forebrain. Nat Neurosci 7:1233-1241. CrossRef Medline

Gemes G, Bangaru ML, Wu HE, Tang Q, Weihrauch D, Koopmeiners AS, Cruikshank JM, Kwok WM, Hogan QH (2011) Store-operated $\mathrm{Ca}^{2+}$ entry in sensory neurons: functional role and the effect of painful nerve injury. J Neurosci 31:3536-3549. CrossRef Medline

Graef IA, Wang F, Charron F, Chen L, Neilson J, Tessier-Lavigne M, Crabtree GR (2003) Neurotrophins and netrins require calcineurin/NFAT signaling to stimulate outgrowth of embryonic axons. Cell 113:657-670. CrossRef Medline

Gross SA, Wissenbach U, Philipp SE, Freichel M, Cavalié A, Flockerzi V (2007) Murine ORAI2 splice variants form functional $\mathrm{Ca}^{2+}$ releaseactivated $\mathrm{Ca}^{2+}$ (CRAC) channels. J Biol Chem 282:19375-19384. CrossRef Medline

Groszer M, Erickson R, Scripture-Adams DD, Lesche R, Trumpp A, Zack JA, Kornblum HI, Liu X, Wu H (2001) Negative regulation of neural stem/ progenitor cell proliferation by the Pten tumor suppressor gene in vivo. Science 294:2186-2189. CrossRef Medline

Groth RD, Mermelstein PG (2003) Brain-derived neurotrophic factor activation of NFAT (nuclear factor of activated T-cells)-dependent transcription: a role for the transcription factor NFATc4 in neurotrophinmediated gene expression. J Neurosci 23:8125-8134. Medline

Groth RD, Coicou LG, Mermelstein PG, Seybold VS (2007) Neurotrophin activation of NFAT-dependent transcription contributes to the regulation of pro-nociceptive genes. J Neurochem 102:1162-1174. CrossRef Medline

Groth RD, Weick JP, Bradley KC, Luoma JI, Aravamudan B, Klug JR, Thomas MJ, Mermelstein PG (2008) D1 dopamine receptor activation of NFATmediated striatal gene expression. Eur J Neurosci 27:31-42. CrossRef Medline

Grynkiewicz G, Poenie M, Tsien RY (1985) A new generation of $\mathrm{Ca}^{2+}$ indicators with greatly improved fluorescence properties. J Biol Chem 260: 3440-3450. Medline

Gu X, Spitzer NC (1995) Distinct aspects of neuronal differentiation encoded by frequency of spontaneous $\mathrm{Ca}^{2+}$ transients. Nature 375:784787. CrossRef Medline

Gwack Y, Srikanth S, Feske S, Cruz-Guilloty F, Oh-hora M, Neems DS, Hogan PG, Rao A (2007) Biochemical and functional characterization of Orai proteins. J Biol Chem 282:16232-16243. CrossRef Medline

Gwack Y, Srikanth S, Oh-Hora M, Hogan PG, Lamperti ED, Yamashita M, Gelinas C, Neems DS, Sasaki Y, Feske S, Prakriya M, Rajewsky K, Rao A (2008) Hair loss and defective T- and B-cell function in mice lacking ORAI1. Mol Cell Biol 28:5209-5222. CrossRef Medline

Hanson MG, Milner LD, Landmesser LT (2008) Spontaneous rhythmic activity in early chick spinal cord influences distinct motor axon pathfinding decisions. Brain Res Rev 57:77-85. CrossRef Medline

Hogan PG, Chen L, Nardone J, Rao A (2003) Transcriptional regulation by calcium, calcineurin, and NFAT. Genes Dev 17:2205-2232. CrossRef Medline

Hogan PG, Lewis RS, Rao A (2010) Molecular basis of calcium signaling in lymphocytes: STIM and ORAI. Annu Rev Immunol 28:491-533. CrossRef Medline

Imura T, Kornblum HI, Sofroniew MV (2003) The predominant neural stem cell isolated from postnatal and adult forebrain but not early embryonic forebrain expresses GFAP. J Neurosci 23:2824-2832. Medline

Jairaman A, Prakriya M (2013) Molecular pharmacology of store-operated CRAC channels. Channels (Austin) 7:402-414. CrossRef Medline

Kaneko N, Okano H, Sawamoto K (2006) Role of the cholinergic system in 
regulating survival of newborn neurons in the adult mouse dentate gyrus and olfactory bulb. Genes Cells 11:1145-1159. CrossRef Medline

Kao SC, Wu H, Xie J, Chang CP, Ranish JA, Graef IA, Crabtree GR (2009) Calcineurin/NFAT signaling is required for neuregulin-regulated Schwann cell differentiation. Science 323:651-654. CrossRef Medline

Kar P, Nelson C, Parekh AB (2011) Selective activation of the transcription factor NFAT1 by calcium microdomains near $\mathrm{Ca}^{2+}$ release-activated $\mathrm{Ca}^{2+}$ (CRAC) channels. J Biol Chem 286:14795-14803. CrossRef Medline

Karpurapu M, Wang D, Singh NK, Li Q, Rao GN (2008) NFATc1 targets cyclin A in the regulation of vascular smooth muscle cell multiplication during restenosis. J Biol Chem 283:26577-26590. CrossRef Medline

Karpurapu M, Wang D, Van Quyen D, Kim TK, Kundumani-Sridharan V, Pulusani S, Rao GN (2010) Cyclin D1 is a bona fide target gene of NFATcl and is sufficient in the mediation of injury-induced vascular wall remodeling. J Biol Chem 285:3510-3523. CrossRef Medline

Klejman ME, Gruszczynska-Biegala J, Skibinska-Kijek A, Wisniewska MB, Misztal K, Blazejczyk M, Bojarski L, Kuznicki J (2009) Expression of STIM1 in brain and puncta-like co-localization of STIM1 and ORAI1 upon depletion of $\mathrm{Ca}^{2+}$ store in neurons. Neurochem Int 54:49-55. CrossRef Medline

Komuro H, Rakic P (1996) Intracellular $\mathrm{Ca}^{2+}$ fluctuations modulate the rate of neuronal migration. Neuron 17:275-285. CrossRef Medline

Leclerc C, Webb SE, Daguzan C, Moreau M, Miller AL (2000) Imaging patterns of calcium transients during neural induction in Xenopus laevis embryos. J Cell Sci 113:3519-3529. Medline

Lendahl U, Zimmerman LB, McKay RD (1990) CNS stem cells express a new class of intermediate filament protein. Cell 60:585-595. CrossRef Medline

Lewis RS (2011) Store-operated calcium channels: new perspectives on mechanism and function. Cold Spring Harb Perspect Biol. 3:a003970. CrossRef Medline

Li BS, Ma W, Zhang L, Barker JL, Stenger DA, Pant HC (2001) Activation of phosphatidylinositol-3 kinase (PI-3K) and extracellular regulated kinases (Erk1/2) is involved in muscarinic receptor-mediated DNA synthesis in neural progenitor cells. J Neurosci 21:1569-1579. Medline

Li M, Chen C, Zhou Z, Xu S, Yu Z (2012) A TRPC1-mediated increase in store-operated $\mathrm{Ca}^{2+}$ entry is required for the proliferation of adult hippocampal neural progenitor cells. Cell Calcium 51:486-496. CrossRef Medline

Lin JH, Takano T, Arcuino G, Wang X, Hu F, Darzynkiewicz Z, Nunes M, Goldman SA, Nedergaard M (2007) Purinergic signaling regulates neural progenitor cell expansion and neurogenesis. Dev Biol 302:356-366. CrossRef Medline

Liu H, Hughes JD, Rollins S, Chen B, Perkins E (2011) Calcium entry via ORAI1 regulates glioblastoma cell proliferation and apoptosis. Exp Mol Pathol 91:753-760. CrossRef Medline

Ma W, Maric D, Li BS, Hu Q, Andreadis JD, Grant GM, Liu QY, Shaffer KM, Chang YH, Zhang L, Pancrazio JJ, Pant HC, Stenger DA, Barker JL (2000) Acetylcholine stimulates cortical precursor cell proliferation in vitro via muscarinic receptor activation and MAP kinase phosphorylation. Eur J Neurosci 12:1227-1240. CrossRef Medline

Maric D, Maric I, Barker JL (2000) Developmental changes in cell calcium homeostasis during neurogenesis of the embryonic rat cerebral cortex. Cereb Cortex 10:561-573. CrossRef Medline

Maric D, Maric I, Chang YH, Barker JL (2003) Prospective cell sorting of embryonic rat neural stem cells and neuronal and glial progenitors reveals selective effects of basic fibroblast growth factor and epidermal growth factor on self-renewal and differentiation. J Neurosci 23:240-251. Medline

McNally BA, Prakriya M (2012) Permeation, selectivity and gating in storeoperated CRAC channels. J Physiol 590:4179-4191. CrossRef Medline

McNally BA, Yamashita M, Engh A, Prakriya M (2009) Structural determinants of ion permeation in CRAC channels. Proc Natl Acad Sci U S A 106:22516-22521. CrossRef Medline

McNally BA, Somasundaram A, Yamashita M, Prakriya M (2012) Gated regulation of CRAC channel ion selectivity by STIM1. Nature 482:241245. CrossRef Medline

Merkle FT, Alvarez-Buylla A (2006) Neural stem cells in mammalian development. Curr Opin Cell Biol 18:704-709. CrossRef Medline

Mishra SK, Braun N, Shukla V, Füllgrabe M, Schomerus C, Korf HW, Gachet C, Ikehara Y, Sévigny J, Robson SC, Zimmermann H (2006) Extracellular nu- cleotide signaling in adult neural stem cells: synergism with growth factormediated cellular proliferation. Development 133:675-684. CrossRef Medline

Moe MC, Varghese M, Danilov AI, Westerlund U, Ramm-Pettersen J, Brundin L, Svensson M, Berg-Johnsen J, Langmoen IA (2005) Multipotent progenitor cells from the adult human brain: neurophysiological differentiation to mature neurons. Brain 128:2189-2199. CrossRef Medline

Morte MI, Carreira BP, Machado V, Carmo A, Nunes-Correia I, Carvalho CM, Araujo IM (2013) Evaluation of proliferation of neural stem cells in vitro and in vivo. Curr Protoc Stem Cell Biol Chapter 2:Unit 2D.14. CrossRef Medline

Motiani RK, Hyzinski-García MC, Zhang X, Henkel MM, Abdullaev IF, Kuo YH, Matrougui K, Mongin AA, Trebak M (2013) STIM1 and Orail mediate CRAC channel activity and are essential for human glioblastoma invasion. Pflugers Arch 465:1249-1260. CrossRef Medline

Munaron L, Antoniotti S, Lovisolo D (2004) Intracellular calcium signals and control of cell proliferation: how many mechanisms? J Cell Mol Med 8:161-168. CrossRef Medline

Nakanishi S, Okazawa M (2006) Membrane potential-regulated $\mathrm{Ca}^{2+}$ signalling in development and maturation of mammalian cerebellar granule cells. J Physiol 575:389-395. CrossRef Medline

Navarro-Borelly L, Somasundaram A, Yamashita M, Ren D, Miller RJ, Prakriya M (2008) STIM1-Orail interactions and Orail conformational changes revealed by live-cell FRET microscopy. J Physiol 586:53835401. CrossRef Medline

Neher E (1986) Concentration profiles of intracellular calcium in the presence of a diffusible chelator. Experimental Brain Research Series 14:80-96.

Nguyen T, Di Giovanni S (2008) NFAT signaling in neural development and axon growth. Int J Dev Neurosci 26:141-145. CrossRef Medline

Oh-Hora M, Yamashita M, Hogan PG, Sharma S, Lamperti E, Chung W, Prakriya M, Feske S, Rao A (2008) Dual functions for the endoplasmic reticulum calcium sensors STIM1 and STIM2 in T cell activation and tolerance. Nat Immunol 9:432-443. CrossRef Medline

Oliveria SF, Dell'Acqua ML, Sather WA (2007) AKAP79/150 anchoring of calcineurin controls neuronal L-type $\mathrm{Ca}^{2+}$ channel activity and nuclear signaling. Neuron 55:261-275. CrossRef Medline

Owens DF, Kriegstein AR (1998) Patterns of intracellular calcium fluctuation in precursor cells of the neocortical ventricular zone. J Neurosci 18:5374-5388. Medline

Pastrana E, Silva-Vargas V, Doetsch F (2011) Eyes wide open: a critical review of sphere-formation as an assay for stem cells. Cell Stem Cell 8:486498. CrossRef Medline

Pathania M, Yan LD, Bordey A (2010) A symphony of signals conducts early and late stages of adult neurogenesis. Neuropharmacology 58:865-876. CrossRef Medline

Platel JC, Dave KA, Bordey A (2008) Control of neuroblast production and migration by converging GABA and glutamate signals in the postnatal forebrain. J Physiol 586:3739-3743. CrossRef Medline

Prakriya M (2009) The molecular physiology of CRAC channels. Immunol Rev 231:88-98. CrossRef Medline

Prakriya M, Lewis RS (2001) Potentiation and inhibition of $\mathrm{Ca}^{2+}$ releaseactivated $\mathrm{Ca}^{2+}$ channels by 2-aminoethyldiphenyl borate (2-APB) occurs independently of $\mathrm{IP}_{3}$ receptors. J Physiol 536:3-19. CrossRef Medline

Prakriya M, Lingle CJ (2000) Activation of BK channels in rat chromaffin cells requires summation of $\mathrm{Ca}^{2+}$ influx from multiple $\mathrm{Ca}^{2+}$ channels. J Neurophysiol 84:1123-1135. Medline

Prakriya M, Solaro CR, Lingle CJ (1996) $\left[\mathrm{Ca}^{2+}\right]_{\mathrm{i}}$ elevations detected by BK channels during $\mathrm{Ca}^{2+}$ influx and muscarine-mediated release of $\mathrm{Ca}^{2+}$ from intracellular stores in rat chromaffin cells. J Neurosci 16:4344-4359. Medline

Prenzel N, Fischer OM, Streit S, Hart S, Ullrich A (2001) The epidermal growth factor receptor family as a central element for cellular signal transduction and diversification. Endocr Relat Cancer 8:11-31. CrossRef Medline

Resende RR, Adhikari A (2009) Cholinergic receptor pathways involved in apoptosis, cell proliferation and neuronal differentiation. Cell Commun Signal 7:20. CrossRef Medline

Reynolds BA, Rietze RL (2005) Neural stem cells and neurospheres-reevaluating the relationship. Nat Methods 2:333-336. CrossRef Medline

Reynolds BA, Tetzlaff W, Weiss S (1992) A multipotent EGF-responsive 
striatal embryonic progenitor cell produces neurons and astrocytes. J Neurosci 12:4565-4574. Medline

Roberts WM, Jacobs RA, Hudspeth AJ (1990) Colocalization of ion channels involved in frequency selectivity and synaptic transmission at presynaptic active zones of hair cells. J Neurosci 10:3664-3684. Medline

Rozov A, Burnashev N, Sakmann B, Neher E (2001) Transmitter release modulation by intracellular $\mathrm{Ca}^{2+}$ buffers in facilitating and depressing nerve terminals of pyramidal cells in layer $2 / 3$ of the rat neocortex indicates a target cell-specific difference in presynaptic calcium dynamics. J Physiol 531:807-826. CrossRef Medline

Sakaki Y, Sugioka M, Fukuda Y, Yamashita M (1997) Capacitative $\mathrm{Ca}^{2+}$ influx in the neural retina of chick embryo. J Neurobiol 32:62-68. CrossRef Medline

Sée V, Rajala NK, Spiller DG, White MR (2004) Calcium-dependent regulation of the cell cycle via a novel MAPK-NF-kappaB pathway in Swiss 3T3 cells. J Cell Biol 166:661-672. CrossRef Medline

Singaravelu K, Lohr C, Deitmer JW (2008) Calcium-independent phospholipase A2 mediates store-operated calcium entry in rat cerebellar granule cells. Cerebellum 7:467-481. CrossRef Medline

Singh G, Singh SK, König A, Reutlinger K, Nye MD, Adhikary T, Eilers M, Gress TM, Fernandez-Zapico ME, Ellenrieder V (2010) Sequential activation of NFAT and c-Myc transcription factors mediates the TGF-beta switch from a suppressor to a promoter of cancer cell proliferation. J Biol Chem 285:27241-27250. CrossRef Medline

Skibinska-Kijek A, Wisniewska MB, Gruszczynska-Biegala J, Methner A, Kuznicki J (2009) Immunolocalization of STIM1 in the mouse brain. Acta Neurobiol Exp (Warsz) 69:413-428. Medline

Spitzer NC, Root CM, Borodinsky LN (2004) Orchestrating neuronal differentiation: patterns of $\mathrm{Ca}^{2+}$ spikes specify transmitter choice. Trends Neurosci 27:415-421. CrossRef Medline

Spitzer NC, Borodinsky LN, Root CM (2005) Homeostatic activitydependent paradigm for neurotransmitter specification. Cell Calcium 37: 417-423. CrossRef Medline
Steinbeck JA, Henke N, Opatz J, Gruszczynska-Biegala J, Schneider L, Theiss S, Hamacher N, Steinfarz B, Golz S, Brüstle O, Kuznicki J, Methner A (2011) Store-operated calcium entry modulates neuronal network activity in a model of chronic epilepsy. Exp Neurol 232:185-194. CrossRef Medline

Stern MD (1992) Buffering of calcium in the vicinity of a channel pore. Cell Calcium 13:183-192. CrossRef Medline

Ullrich A, Schlessinger J (1990) Signal transduction by receptors with tyrosine kinase activity. Cell 61:203-212. CrossRef Medline

Venkiteswaran G, Hasan G (2009) Intracellular $\mathrm{Ca}^{2+}$ signaling and storeoperated $\mathrm{Ca}^{2+}$ entry are required in Drosophila neurons for flight. Proc Natl Acad Sci U S A 106:10326-10331. CrossRef Medline

Weissman TA, Riquelme PA, Ivic L, Flint AC, Kriegstein AR (2004) Calcium waves propagate through radial glial cells and modulate proliferation in the developing neocortex. Neuron 43:647-661. CrossRef Medline

Wissenbach U, Philipp SE, Gross SA, Cavalié A, Flockerzi V (2007) Primary structure, chromosomal localization and expression in immune cells of the murine ORAI and STIM genes. Cell Calcium 42:439-446. CrossRef Medline

Yasuda T, Adams DJ (2010) Physiological roles of ion channels in adult neural stem cells and their progeny. J Neurochem 114:946-959. CrossRef Medline

Yasuda T, Bartlett PF, Adams DJ (2008) K(ir) and K(v) channels regulate electrical properties and proliferation of adult neural precursor cells. Mol Cell Neurosci 37:284-297. CrossRef Medline

Zhang W, Couldwell WT, Song H, Takano T, Lin JH, Nedergaard M (2000) Tamoxifen-induced enhancement of calcium signaling in glioma and MCF-7 breast cancer cells. Cancer Res 60:5395-5400. Medline

Zheng JQ, Poo MM (2007) Calcium signaling in neuronal motility. Annu Rev Cell Dev Biol 23:375-404. CrossRef Medline

Zitt C, Strauss B, Schwarz EC, Spaeth N, Rast G, Hatzelmann A, Hoth M (2004) Potent inhibition of $\mathrm{Ca}^{2+}$ release-activated $\mathrm{Ca}^{2+}$ channels and T-lymphocyte activation by the pyrazole derivative BTP2. J Biol Chem 279:12427-12437. CrossRef Medline 